\title{
Do Market Imperfections Give Rise to Financial Constraints? A Growth Type Explanation for the Sensitivity of Investment to Cash Flow*
}

\section{Xueping Wu and Chau Kin Au Yeung}

This version: August 2012

\begin{abstract}
We identify a firm's growth type by its valuation volatility which proxies for the extent to which asymmetric information arises from growth opportunities rather than from assets-in-place. We show that firm investment style (measured by $R \& D /[C a p e x+R \& D]$ ) is persistent and positively aligned with growth type. The sensitivity of investment to cash flow has a monotonic negative relationship with growth type. Additionally, the sensitivity of equity-anddebt-financing-differential to market conditions increases with investment style, reflecting a growth-type-aligned pecking order in financing. These findings demonstrate that firms invest and seek financing in a manner compatible with their growth type. This suggests that informational imperfections do not necessarily impose financing constraints on firms listed on well-functioning capital markets.
\end{abstract}

Keywords: Investment, Informational Imperfections, Growth Type, Financing Constraints JEL classification: G30, G31, G32, D92

${ }^{*}$ Corresponding author: Xueping Wu. Address: Department of Economics and Finance, City University of Hong Kong, 83 Tat Chee Avenue, Kowloon, Hong Kong; Tel: (852) 3442 7577; Fax: (852) 3442 0195; email: efxpwu@cityu.edu.hk; coauthor address: (Au Yeung) Department of Economics and Finance, City University of Hong Kong; email: chaukin@cityu.edu.hk. The authors wish to thank Lawrence Khoo, Jarrad Harford and seminar/conference participants at the 2011 City University of Hong Kong International Conference on Corporate Finance and Financial Markets for helpful discussions and comments. 


\section{Introduction}

It is commonly believed that market imperfections impose financing constraints on corporate investment and impede economic growth. But neoclassical theory insists that investment opportunities have an overriding effect on investment despite market imperfections. This paper shows that for listed firms (which unlike private firms, have access to external finance in the capital markets), market imperfections do not hinder corporate investment, to the extent that growth-type-compatible investment and financing effectively mitigates asymmetric informational imperfections.

What we call growth-type-compatible investment and financing-or growth type compatibility — characterizes the equilibrium in which investment styles (characterized by investment in intangibles versus fixed assets) and optimal financing arrangements (equity versus debt financing) go hand-in-hand with corresponding firm growth types. We identify a firm’s growth type by its valuation volatility which proxies for the extent to which asymmetric information arises from growth opportunities rather than from assets-in-place. We argue that high growth type firms have high valuation volatility and high growth, befitting their informational environment where asymmetric information about growth opportunities dominates. On the other hand, low growth type firms have low valuation volatility and low growth, befitting their informational environment which is dominated by asymmetric information about assets-inplace.

Growth type compatibility starts with the premise that firms with a particular growth type attract and accommodate a certain type of competitively available human capital (or knowledge capital). This gives rise to persistent and distinct corporate investment styles and optimal financial policies in response. $\mathrm{Wu}$ and $\mathrm{Au}$ Yeung (2011, 2012) find that growth type 
compatibility contributes to the persistence in both leverage ratios and propensity to pay dividends.

How do we know that market imperfections do not necessarily give rise to financial constraints? The answer lies in examining the sensitivity of investment to cash flow (investmentcash flow sensitivity, ICFS). Fazzari, Hubbard and Petersen (1988) use a standard investment regression to introduce ICFS as a measure for the degree of financial constraints a firm is experiencing. They suggest that ICFS increases with the wedge between the costs of external and internal finance. But Kaplan and Zingales (1997) argue that firm-specific variations in investment opportunities intricately affect corporate financing, undermining the financialconstraint interpretation of ICFS. Fazzari, Hubbard and Petersen (2000) disagree and provide a follow-up rebuttal to Kaplan and Zingales’ (1997) critique. In response, Kaplan and Zingles (2000) point out: “Fazzari, Hubbard and Petersen’s (2000) defense of investment-cash flow sensitivities as measures of financial constraints, distracts attention from the more important question: what causes this sensitivity?”

We suggest that a firm's growth type rather than the degree of financial constraints better explains ICFS. Using CRSP and Compustat data for 1971-2006 on U.S. nonfinancial firms, we find a monotonic negative relation between ICFS and growth type. This finding has profound implications.

A firm's growth type (whose measurement is detailed below), is established at the beginning of its listed life. A firms’ investment style is closely related to its growth type. We find that high-growth type firms have heavy investments in total and undertake much more investment in $R \& D$ or intangibles relative to their investment in fixed assets (measured by Capital Expenditure, Capex), and low-growth type firms do the opposite. 
A firm's financing behavior is also related to its growth type. We find that the capital markets channel much more equity than other funding sources to high growth type firms to facilitate their aggressive investment in $R \& D$. Despite low and often negative earnings due to huge R\&D expenses, this type of firm defies Myers’ (1984) pecking order in financing and can sustain high growth for a surprisingly long period, producing a low ICFS. By contrast, low growth type firms have high ICFS because this kind of firm typically focuses on tangible investments, grows slowly, produces steadily high earnings, pays dividends and often obeys Myers’ (1984) pecking order in financing.

One may argue that the low ICFS of high-growth type firms implies that they are less financially constrained, consistent with a financial constraint explanation for ICFS. But if this is true, financial constraints are not of first-order importance in corporate finance, because financial constraints fail to hinder high growth when there is a great deal of uncertainty. A better explanation is that the monotonic negative relationship between ICFS and growth type demonstrates the ability of growth type compatibility to mitigate informational imperfections and allow firms to grow on distinct growth paths according to their growth types.

To make growth type compatibility empirically tractable, we start off by defining a firm’s asymmetric information using the standard deviation of its monthly market-to-book ratios (M/B) in each year. As the existing literature commonly uses $\mathrm{M} / \mathrm{B}$ to proxy for investment opportunities, we use the within-firm monthly standard deviation of $\mathrm{M} / \mathrm{B}$, to measure the extent to which asymmetric information arises more from growth opportunities than from assets-inplace. As a result, we use this second moment of M/B as a proxy for Asymmetric Information type, $A I=\sigma(M / B)$. AI parsimoniously identifies firm growth type: high AI indicates high-growth 
type and low AI indicates low-growth type, while AI close to median indicates a mixed-growth type. Using AI to classify growth types has a solid theoretical basis.

The generalized Myers-Majluf model developed by Cooney and Kalay (1993) and Wu and Wang (2005) shows, while the type of asymmetric information about assets-in-place tends to produce the classic Myers and Majluf (1984) adverse selection problem, the type of asymmetric information about growth opportunities can facilitate new equity issuance. As a result, an increase in uncertainty about growth when market conditions improve does not necessarily create adverse selection, but can facilitate new equity issues ( $\mathrm{Wu}$ and $\mathrm{Wang}, 2005) .{ }^{1}$ In other words, a higher value of AI is associated with higher uncertainty over new investments, and hence is more likely to indicate the type of asymmetric information on growth opportunities, but it does not necessarily suggest a higher degree of financing constraints.

Fama and French (2002, 2005) already show evidence to the effect that Myers’ (1984) pecking order in financing (with new equity as a last resort) is not a complete description of corporate financing behavior (see also Myers [2003]). The generalized Myers-Majluf model is able to shed light on this finding. The truth is that equity issuers may not typically be lemons, especially among high-growth type firms. This generalized view helps us understand that new equity financing can provide overwhelming benefits to both existing and new investors of human capital intensive or intangible firms, which become more and more common as described in Zingales (2000).

\footnotetext{
${ }^{1}$ The recent asset pricing literature has also shown that an increase in uncertainty about future profitability improves the current market-to-book ratio and lowers the cost of equity (Pastor and Veronesi [2003, 2005]). However, unlike the generalized Myers-Majluf model, this literature is unable to address one of the central issues in corporate finance: tensions between old and new investors regarding external finance.
} 
We find that high and low annual values of AI are surprisingly persistent, and growthrelated firm fundamentals are well aligned with AI. For example, high and low AI firms tend to have high and low market-to-book ratios and rates of growth in assets and sales. So a sort on measured firm growth type through AI is able to reveal a meaningful cross section of firm fundamentals, reflecting a sustainable equilibrium characterized by growth type compatibility.

We show that corporate investment style, measured by $R \& D /(C a p e x+R \& D)$, also denoted as Investyle, is closely related to AI. More precisely, Investyle has a within-firm median rank correlation of 0.43 with $\mathrm{AI}$; Like $\mathrm{AI}$, Investyle persists over time. This persistence in growth-type-aligned investment style tends to tie down financing behavior. ${ }^{2}$

We find that the sensitivity of equity and debt (or External) Financing Differential, EFD, to lagged market-to-book ratio (a proxy for investment opportunities or market conditions) increases with Investyle. This suggests a growth-type-aligned pecking order in financing, consistent with the generalized Myers-Majluf model.

For high-growth type firms, high growth and heavy equity financing go hand-in-hand, despite a great deal of valuation uncertainty. Since these patterns are highly persistent over time, they cannot be due to exploitable market timing as described in Stein (1996). While we do not deny that mispricing or non-fundamental movements occur in any uncertain situation, we do not need to assume mispricing to build an argument in favor of the growth-type-aligned pecking order in financing. Few would accept that mispricing facilitates persistently high growth, but asymmetric informational imperfections tell a lot about a meaningful cross section of growth-

\footnotetext{
${ }^{2}$ The keyword is persistence. Welch (2004) argues that the existing theories in the literature cannot really explain why capital structure is persistent.
} 
related firm fundamentals in a sustainable equilibrium characterized by growth type compatibility.

It is true that our growth type measure, $\mathrm{AI}$, contains information on market-to-book ratio and may be confounded by concurrent market sentiments or mispricing. Yet if genuine growth type persists, growth type identified at the beginning may suffice to capture the genuine growth type and this initial growth type has an advantage of mitigating the endogeneity problems prevalent in corporate finance. Thus, we use initial growth type, Initial AI, as an explanatory variable-namely, the within-firm time-series average of AI over year 0, 1 and 2 (where year 0 is a firm's earliest data reporting year in the total sample).

Initial AI is our main independent variable to explain ICFS in standard investment regressions. We also use within-firm time-series medians of the $\mathrm{KZ}$ index (introduced by Lamont, Polk and Saa-Reguejo [2001]), and the WW index (introduced by Whited and Wu, 2006), commonly used in the literature, as control variables for financial constraints. We use Initial AI along with these financial constraints indexes to interact with both lagged CF/A (cash flow scaled by total assets) and Q (or Tobin's q, which as a correlation of 0.98 with M/B) to explain current capital investment, Capex/A. We consider the interaction with Q because the role of stock market information (like through M/B) in affecting investment in Barro (1990) may be only pronounced for certain firms (Baker, Stein and Wurgler [2003]).

We find that ICFS (the slope estimate for CF/A) decreases with Initial AI and the WW index, but increases with the KZ index. Note that in the panel data, like the time-series median for a financial-constraints index, Initial AI cuts across firms only once. In the literature, a higher value of the $\mathrm{KZ}$ or WW index usually means a higher degree of financial constraints. Thus, 
given this interpretation, only the KZ index shows the correct sign for ICFS to measure financial constraints.

Despite a moderately positive correlation of WW (corr=0.33) and a negative correlation of KZ (-0.28) with Initial AI, the relation between the ICFS and Initial AI remains significantly negative even after controlling for these popular measures for financial constraints. In addition, there are obvious differences in results between Initial AI and the financial constraint indexes.

We find that the Q or stock price sensitivity decreases with Initial AI but increases with both the $\mathrm{KZ}$ and $\mathrm{WW}$ indexes. Given that the $\mathrm{KZ}$ index can be interpreted alternatively as equity dependence (Baker, Stein and Wurgler [2003]) and the WW index can be interpreted alternatively as the "need for external finance” (Hennessy and Whited [2007]), they all show correct signs for the estimates. As for Initial AI, our finding of its negative relation to the stock price sensitivity suggests that capital investment in high-growth type firms is less sensitive to stock prices than that in low-growth type firms. Thus, our high- and low-growth type firms do not imply high and low KZ-index-based equity dependence or high and low WW-index-based need for external finance or both.

The remainder of the paper proceeds as follows. Section II reviews the literature. Section III describes both data and the measures for growth type and financial constraints, and summarizes important firm fundamental characteristics of growth type quintiles. Section IV shows the ICFS estimates by firm quintile. Section V reports the main results. Section VI concludes.

\section{Background of Research on Investment and Financial Constraints}

It is a deeply rooted perception in economics and finance that market imperfections impose financial constraints on corporate investment (see the review in Hubbard [1998]). But empirical 
results that do not square well with this perception from corporate finance research on listed firms have started to emerge. Rajan and Zingales (1995) and Fama and French (2002, 2005) document such findings to the effect that asymmetric informational imperfections do not seem to hinder their financing and hence investment. The debate between Fazzari-Hubbard-Petersen and Kaplan-Zingales which is centered on whether investment-cash flow sensitivities (ICFS) measure financial constraints highlights the need for rethinking theoretical foundations (Zingales [2000]).

Based on the premise that external finance has a cost disadvantage over internal finance in imperfect capital markets, Fazzari, Hubbard and Petersen (1988) introduced ICFS as a measure for the degree of financial constraints. They proposed that ICFS increases with the cost wedge between external and internal funds, the wedge or "lemons premium" deemed to increase with information asymmetries in external finance. After almost a decade in which many studies adopted this ICFS approach, Kaplan and Zingales (1997) contended that ICFS does not measure financial constraints because firm-specific variations in investment opportunities intricately affect corporate financing, creating a non-monotonic relation between ICFS and the size of wedge (see the discussion following equation (6) in Kaplan and Zingales [1997]).

Monotonicity is an important issue in empirical research on ICFS. Most researchers rely on some kind of sorting to classify firms as financially constrained or unconstrained—usually, a cut on some proxy or across a set of proxies for the cost wedge-and then show differential ICFS estimates between the sorted firm groups. For example, Fazzari, Hubbard and Petersen (1988) originally classified financially constrained firms as those that persistently pay small or no dividends and unconstrained firms as those that pay large dividends. This Fazzari-HubbardPetersen (FHP) sorting based on dividend policy shows that constrained firms have a high ICFS, 
whereas unconstrained firms display a low ICFS. However, Kaplan and Zingales (1997, 2000) have since pointed out that such a FHP sorting approach only works if the relationship between the ICFS and the degree of financial constraints is generally monotonic.

If the relationship is non-monotonic, the ICFS may not necessarily measure financial constraints correctly, they argued, because other factors related to investment opportunities but possibly unrelated to financial constraints are likely to have an influence. Conversely, a sorting based on some exogenously determined degree of financial constraints may not necessarily produce the ICFS estimates as expected by Fazzari, Hubbard and Petersen (1988). In other words, the ICFS may reflect a more comprehensive effect than that of financial constraints alone. To back up their argument, Kaplan and Zingales (1997) showed that some obviously unconstrained firms such as those with high interest coverage ratios display a high ICFS estimate, contradicting the claim that ICFS measures the degree of financial constraints. Cleary (1999) subsequently used a large sample and a detailed classification system for firm financial status, and his findings also support the argument of Kaplan and Zingales (1997).

Fazzari, Hubbard and Petersen (2000) disagree and argued that the empirical classification system used by Kaplan and Zingales (1997) is likely to be flawed and fails to identify financial constraints appropriately. In response to this rebuttal, Kaplan and Zingales (2000) contended that their sorting system serves the identification purpose well and reveals the existence of general non-monotonicity that renders using the ICFS as an indicator of financial constraints questionable.

This famous debate has spawned further intensive research on ICFS and financial constraints. Almeida and Campello (2007) acknowledge the non-linear relationship between ICFS and the degree of financial constraints posited by Kaplan and Zingales (1997), and find 
that only among financially constrained firms, ICFS increases with the tangibility of a firm's assets (which is a proxy for pledgeability). This is consistent with the claim that debt capacity is linked to tangibility (Myers [1977]). The causality seems to flow from debt capacity via collaterals to corporate investment (Gan [2007]). But this role of tangibility cannot address why many firms with primarily human capital or intangible assets can invest and grow rapidly.

Other studies have cast further doubt on whether ICFS measures the degree of financial constraints at all. Alti (2003) argues that cash flow contains valuable information about a firm’s investment opportunities, and that the cross-sectional pattern of ICFS is consistent with the predictions of a model with no financing friction. Gomes (2001) concludes that a significant ICFS is likely to be due to a combination of measurement error in Tobin's q (or Q) and identification problems. Using a new estimation technique in an attempt to minimize measurement error, Erickson and Whited (2000) find ICFS insignificant in a structural model, and they point out that the average $\mathrm{Q}$, which is commonly used to replace the hardly measurable marginal Q, is so noisy that it cannot appropriately capture investment opportunities. This suggests that a significant ICFS estimate obtained from standard (reduced-from) investment regressions at best compensates for the measurement error in $\mathrm{Q}$.

These findings raise the question of what, if not the ICFS, reliably measures the degree of financial constraints. Building on the work of Kaplan and Zingales (1997), Lamont, Polk and Saa-Requejo (2001) suggested the KZ index to measure the degree of financial constraints, but in an asset pricing context. The index incorporates several firm characteristics and can be time varying. The higher the $\mathrm{KZ}$ index, the greater the degree of financial constraints it means.

To propose an alternative measure for financial constraints, Almeida, Campello and Weisbach (2004) examine corporate demand for liquidity. They suggest that a firm’s propensity 
to save cash out of cash flow (the cash flow sensitivity of cash) captures the effect of financial constraints effectively. They argue that precautionary saving reflects a high cost of external finance. But cash holdings can come from issuing shares (McLean [2011]). In effect, almost all kinds of firms issue new equity (Fama and French [2005]). Surprisingly, high levels of cash holdings, especially in high growth firms, typically come from new equity issues (Wu and $\mathrm{Au}$ Yeung [2011, 2012]). On the other hand, high cash holdings do not necessarily indicate free cash flow because they do not seem to hinder corporate investment and performance (Mikkelson and Partch [2003]).

In studying financial constraint risk in the contest of asset pricing, Whited and Wu (2006) construct a new financial constraint index, the WW index, based on their structural investment model. The WW index is supposed to proxy for the shadow price of external finance assuming separate exogenous constraints on debt and new equity financing. The correlation of the $\mathrm{KZ}$ and WW indexes is only around 0.13 in our sample, despite much overlap in their components. The WW index includes new firm characteristics such as a firm's sales growth relative to its industry. The higher the WW index, the greater the degree of financial constraints it means.

Despite extensive research on financial constraints, their identification remains somewhat difficult (Moyen [2004])—perhaps because of the endogenous nature of most corporate finance variables. The trouble is that researchers have often reinterpreted the various financial constraint measures that had been proposed. For example, both the KZ and WW indexes can lose the original meaning of financial constraints either slightly or drastically. Baker, Stein and Wurgler (2003) interpret the KZ index as an index of equity dependence. The KZ-index-based equity dependent firms typically have a high leverage and low cash holdings, and they regard these firms as being prone to non-fundamental movements in stock prices in the firms' favor. By 
gauging the cost of external finance using a structural estimation, Hennessy and Whited (2007) suggest that the KZ and WW indexes are better proxies for "external financing need" than for the cost of external finance. At the same time, Hennessy, Levy and Whited (2007) retain the original meaning and treat the WW index as a proxy for financial constraints.

The difficulty academics have encountered in identifying financial constraints with large panel datasets directs our attention back to the neoclassical claim that the importance of investment opportunities overrides the impeding effect of market imperfections, a claim which may be true to the extent that optimal corporate financing arrangements can significantly mitigate asymmetric information problems. This would potentially invalidate the notion that financial constraints bind listed firms due to market imperfections such as asymmetric informational imperfections. But unless we understand how optimal financing arrangements respond to informational imperfections, we are not sure, even if we use structural models, whether or not the neoclassical claim is valid.

\section{Data and Measures for Growth Type and Financial Constraints}

In this section, we first describe the data (Section III.A), define our measure for firm growth type (Section III.B), review popular financial constraint indexes (Section III.C), and then report growth type sorted patterns for important firm characteristics (Section III.D).

\section{A. The Data}

We use a sample of U.S. firms from the Compustat and CRSP databases for 1971-2006. Similar to Fama and French (2001) and Baker, Stein and Wurgler (2003), we pre-process the data as follows. (1) We exclude financials (SIC 6000 - 6999). (2) For each firm, we define event year 0 as the first year in which Compustat reports its market equity value: the stock price (data item: \#199) times common shares outstanding (\#25). (3) We intersect the Compustat firms in year $t$ 
with CRSP (NYSE, AMEX and NASDAQ) firms that have share codes of 10 and 11 and have market equity data for December of year $t$ to be in the CRSP sample of that year. (4) We exclude firms that have annual market equity data for less than three consecutive years. (5) Each year, we exclude firms with assets below $\$ 10$ million, and we restrict book leverage ratio to be no greater than unity, and market-to-book ratio to be no greater than 20 .

Finally, we trim firm-year observations for these variables: firm growth type, AI (defined later), collateral, Tangibility, profitability, E/A, sales growth rate, $\Delta \mathrm{S} / \mathrm{S}$, asset growth rate, $\Delta \mathrm{A} / \mathrm{A}$, cash holdings to total asset ratio, Cash/A, cash flow to total asset ratio, CF/A, tangible investment expenditure to total asset ratio, Capex/A, R\&D to total asset ratio, $\mathrm{R} \& \mathrm{D} / \mathrm{A}$, change in retained earnings to total asset ratio, $\Delta \mathrm{RE} / \mathrm{A}$, net debt issue to total asset ratio, $\Delta \mathrm{Debt} / \mathrm{A}$, and net equity issue to total asset ratio, $\Delta$ Equity/A, by the top and bottom 0.5 percent of each variable, and we do this simultaneously to avoid excessive trimming. Except growth type and the financial constraint indexes which we detail below, the detailed construction of other variables we use in this paper is reported in Appendix.

\section{B. Initial AI and Growth Type}

We identify a firm's growth type based on its asymmetric informational imperfection type. Each year, we calculate a firm's standard deviation of monthly market-to-book ratios (M/B). M/B equals $\left(\mathrm{B}+\mathrm{NPV} \mathrm{V}_{\mathrm{A}}+\mathrm{NPV} \mathrm{V}_{\mathrm{F}}\right) / \mathrm{B}$ where $\mathrm{B}$ is the book value of assets-in-place, $\mathrm{NPV}_{\mathrm{A}}$ is the net present value of the assets-in-place or $\left(\mathrm{B}+\mathrm{NPV} \mathrm{V}_{\mathrm{A}}\right)$ is the total market value of assets-in-place, and $\mathrm{NPV}_{\mathrm{F}}$ is the net present value of the firm's future investments. A firm's market value is $M=B+N P V_{A}$ $+\mathrm{NPV}_{\mathrm{F}}$. Thus, $\sigma^{2}(\mathrm{M} / \mathrm{B})=\sigma^{2}\left(\mathrm{NPV}_{\mathrm{A}} / \mathrm{B}\right)+\sigma^{2}\left(\mathrm{NPV}_{\mathrm{F}} / \mathrm{B}\right)+\rho \sigma\left(\mathrm{NPV}_{\mathrm{A}} / \mathrm{B}\right) \sigma\left(\mathrm{NPV}_{\mathrm{F}} / \mathrm{B}\right)$. Since it is difficult to separate out $E\left[N P V_{A}\right]$ let alone $E\left[N P V_{F}\right]$ in the first moment of $M / B$, the empirical literature commonly uses the $\mathrm{M} / \mathrm{B}$ ratio as a proxy for expected growth opportunities $\mathrm{E}\left[\mathrm{NPV} \mathrm{F}_{\mathrm{F}} / \mathrm{B}\right.$ ]. 
Likewise, we can use the second moment of $\mathrm{M} / \mathrm{B}$ or $\sigma(\mathrm{M} / \mathrm{B})$ as a proxy for the expected uncertainty over growth opportunities or the extent to which asymmetric information arises more from growth opportunities than from assets-in-place.

We use $\mathrm{AI}=\sigma(\mathrm{M} / \mathrm{B})$ to identify a firm's growth type parsimoniously. High AI indicates high-growth type and low AI indicates low-growth type, while AI close to median indicates a mixed-growth type. This classification means that high growth type firms have high valuation volatility and high growth, befitting their informational environment where asymmetric information about growth opportunities dominates. On the other hand, low growth type firms have low valuation volatility and low growth, befitting their informational environment which is dominated by asymmetric information about assets-in-place.

This identification of growth type is in the same spirit as in Wu and Au Yeung (2011, 2012) who propose a two-way independent sort on initial market-to-book ratio and asset tangibility with median breakpoints across all firms. For each firm, an initial value is the annual average over the first three years after the firm enters the data set. They sort out three firm growth types: low-growth type (G1) means firms with low market-to-book ratios and high tangibility, high-growth type (G3) refers to firms with high market-to-book ratio and low tangibility, and mixed-growth type (G2) includes the other firms with less lopsided market-tobook and tangibility.

In a world with asymmetric information, they argue, low-growth firms (G1) are the most likely to have more asymmetric information about assets-in-place than about investment opportunities; conversely, high-growth firms (G3) are the most likely to have more asymmetric information about growth opportunities than about assets-in-place. The G3 firms are likely to correspond with Zingales' (2000) 'New Firm' which is human capital intensive so that 
intangibles including growth opportunities are not necessarily firm specific and whose attachment to the firm can be very uncertain. As it is unclear which type of asymmetric information predominates in the other cases, these firms are of mixed-growth type (G2).

Wu and Au Yeung $(2011,2012)$ find that firms of the three growth types show persistent and distinct combinations of market-to-book and asset tangibility over time, tending to validate the taxonomy. Using AI to identify growth type has an advantage because AI is a continuous variable and allows a finer measurement of the extent to which asymmetric information arises more from growth than from assets in place. To limit the possibility of reverse causality that runs from current corporate policies to growth type, we use initial values of AI; a firm's Initial-AI is the average AI over the first three years after the firm enters the data set.

\section{The KZ Index, the WW Index and the SA Index}

In the literature, there have been some popular measures for financial constraints, such as the KZ index, the WW index, and the SA index.

Kaplan and Zingales (1997) did not construct the KZ index, but Lamont, Polk and SaaRequejo (2001) did on the basis of the former's work. To study financial constraint risk in asset pricing, they propose the $\mathrm{KZ}$ index as a measure of the degree of financial constraints as follows:

$$
K Z_{i, t}=-1.002 \frac{C F_{i, t}}{A_{i, t-1}}-39.368 \frac{\text { Div }_{i, t}}{A_{i, t-1}}-1.315 \frac{C_{i, t}}{A_{i, t-1}}+3.139 \text { Lev }_{i, t}+0.283 Q_{i, t}
$$

The KZ index cuts across several firm characteristics. The coefficients must be estimated with panel data over an extended period, but component firm characteristics are allowed to vary to obtain a time-varying firm-specific index of financial constraints. For firm $i$ in year $t$, the lower the cash flow, the lower the dividends, the lower the cash holdings, the higher the leverage 
ratio, or the better the growth prospects, the higher the $\mathrm{KZ}$ index and hence the degree of financial constraints are.

Whited and Wu (2006) propose their WW index, which derives from a structural investment model they use to study financial constraint risk for asset pricing purposes. The WW index for firm $i$ in year $t$ is

$$
W W_{i, t}=-0.091 C F_{i, t}-0.062 \operatorname{DIVPOS}_{i, t}+0.021 T L T D_{i, t}-0.044 L N T A_{i, t}+0.102 I_{i, t}-0.035 S G_{i, t}
$$

Like the KZ index, the WW index also contains information on cash flows, dividends, leverage and firm size (the first four variables). But it also includes information on firm growth, such as the firm's sales growth relative to its industry. The higher the WW index, the greater the degree of financial constraints it means.

Hadlock and Pierce (2010) have recently put forward another new measure for financial constraints, the Size-Age or SA index:

$$
S A_{i, t}=-0.737 \text { Size }_{i, t}+0.043 \text { Size }_{i, t}^{2}-0.040 \text { Age }_{i, t}
$$

Size is the $\log$ of inflation-adjusted (to 2004) book assets, and Age is the number of years the firm has been on Compustat with non-missing stock prices. In calculating the SA index, values of size larger than log of $\$ 4.5$ billion and ages greater than 37 years are replaced with those thresholds.

Like the $\mathrm{KZ}$ index, calculating the SA index requires qualitative information from annual corporate statements to infer the degree of financial constraints in the first place, but the estimation in (3) covers more years and uses a much larger sample than the estimation in (1) for the $\mathrm{KZ}$ index. The correlation between the SA index and the $\mathrm{KZ}$ index is moderately negative $(-0.11)$, but its correlation with the WW index is highly positive (0.80), as reported in Hadlock 
and Pierce (2010). Conceptually, the SA index is close to the KZ index, but empirically it is very highly correlated with the WW index which is based on sophisticated structural model fitting.

\section{Fundamental Patterns Sorted by Initial-AI}

We sort the sample of U.S. firms for 1971-2006 into quintiles, according to Initial AI. This produces five portfolios from low Initial-AI quintile 1 to high Initial-AI quintile 5.

Panel A of Table 1 shows that those Initial-AI quintiles predict the same order of future annual AI values (from 0.07 to 0.60 ) over the entire sample period of 1971-2006. Like the three growth types of $\mathrm{Wu}$ and $\mathrm{Au}$ Yeung (2011, 2012), Initial AI captures distinct firm growth type characteristics. There is a good match between the G1, G2 and G3 firms and the Initial-AI quintiles. For example, $75.4 \%$ of the lowest Initial-AI firms (Low) are the low-growth type G1 firms and $77.5 \%$ of the highest Initial-AI firms (High) are the high-growth type G3 firms. Like the G1-G3 sort, an Initial-AI sort produces similar combinations of future $\mathrm{M} / \mathrm{B}$ and asset tangibility. Panel A shows, for example, that the group means of annual M/B ratio and tangibility for the lowest quintile (Low) are 0.82 and 0.60, respectively, whereas those for the highest quintile (High) are 2.77 and 0.39 . Actually, there is a clear pattern in that future M/B ratios line up well (from 0.82 to 2.77 monotonically) with Initial AI (from Low to High) and future asset tangibility in reverse order (from 0.60 to 0.39 monotonically) with Initial AI. This suggests that Initial AI also does a good job of revealing firm growth type.

Panel B of Table 1 shows monotonic Initial-AI-sorted patterns are evident for the KZ index, the WW index, and the SA index as well. The KZ index (from 0.61 to -0.71 ) lines up negatively with Initial AI (from Low to High), and both the WW index (from -0.90 to -0.80 ) and the SA index (from -3.33 to -2.68 ) line up, however, positively. In addition, Initial-AI sorts also produce monotonic patterns for firm characteristics - that are important components of one or 
more measures of financial constraints-leverage ratio, likelihood that a firm pays dividends, firm size and firm age. More precisely, from the lowest quintile (Low) to the highest (High), the future annual group means are from 0.32 to 0.14 for leverage, from 68.1 to $24.6 \%$ for likelihood of paying dividends, from $\$ 19.76$ to 18.14 million for the logarithm of assets (LnA), and from 13.59 to 6.48 years for firm age, all progressing monotonically. The relations between these variables and between the relevant components and the financial constraint indexes are largely consistent with the findings of prior studies. Our message here is that these relations may all contain information about firm growth-related fundamentals which are also relevant to growth type.

So how closely does the degree of financial constraints relate to our growth type classification? Panel A of Table 2 shows that the annual average correlation of Initial AI with the $\mathrm{KZ}$ index is -0.16 ; and it is 0.18 with the $\mathrm{WW}$ index and 0.20 with the SA index. If we measure growth type each year instead of fixing it initially, the average correlation numbers increase in magnitude to $-0.23,0.23$, and 0.29 , respectively (the second column in Panel A). The average correlation in Panel A of Table 2 is the time-series average of the annual cross-sectional correlations. There can be different computation methods: for example, one grand cross-sectional correlation of within-firm medians over the whole sample period (Panel B) and one grand crosssectional rank correlation of within-firm median ranks (Panel C). Each method in Table 2 yields modest correlation between the measurements for growth type and financial constraints. So clearly it will be necessary to control for these financial constraint indexes in the tests later.

Referring back to Table 1, Panel C shows that tangible investment, Capex/A, does not show a monotonic pattern across the Initial-AI quintiles, but R\&D/A lines up well. Firms in the lowest Initial-AI quintile 1 (Low) invest of $0.7 \%$ of total assets in $R \& D$ annually on average, whereas 
firms in the highest Initial-AI quintile 5 (High) an annual average of $7.5 \%$ of total assets. Because of the distinct tilt in their investments toward R\&D, high growth firms have high annual rates of growth in assets and sales, but produce low earnings compared with low growth firms. As shown in Panel C, firms in Initial-AI quintile 1 grow at an annual rate of $10.1 \%$ in terms of total assets and $11.2 \%$ in terms of sales, whereas firms in Initial-AI quintile 5 on average grow at a much high rate of $42.2 \%$ in total assets and $40.0 \%$ in sales. In reverse order, the slowest growing firms (Low) generate, on average, high profitability, E/A, of 12.1\%, while the fastest growing firms (High) have average profitability of 9.9\%. Notice that the within-quintile ex post dispersion in profitability is smallest for the quintile 1 firms, from loss-making firms with average negative earnings of $-6.1 \%$ to profitable firms with average earnings of $12.9 \%$. It is biggest for quintile 5 firms, from $-17.5 \%$ to $18.5 \%$. Cao, Simin and Zhao (2008) show firms with a lot of growth options tend to have high future volatility. Wu and Au Yeung (2011, 2012) have also pointed out that high uncertainty about growth prospects goes with high growth rates.

The next question is how firms finance their growth. Panel D of Table 1 shows that firms in quintile 5 (High) on average generate the lowest cash flows (CF/A, at 3.8\% of total assets), but they do enjoy the largest cash holdings (26.4\% of total assets). By contrast, firms in quintile 1 (Low) have relatively high cash flows (7.3\%) but low cash holdings (6.3\%). The funding sources reveal what is going on.

Looking at the three funding sources, quintile 1 (Low) firms rely on all of them-retained earnings ( $\Delta \mathrm{RE} / \mathrm{A}$ at $1.1 \%$ of total assets), net debt ( $\Delta \mathrm{Debt} / \mathrm{A}$ at $1.0 \%)$ and net equity ( $\Delta \mathrm{Equity} / \mathrm{A}$ at 0.4\%). This pattern is consistent with Myer's (1984) pecking order in financing. But this pecking order is clearly reversed for the two highest Initial-AI quintiles. Quintile 5 (High) firms 
on average have a change in retained earnings (-2.3\%), a positive net debt $(1.4 \%)$ and net equity (a startling 8.3\%) annually.

The negative change in retained earnings hardly suggests meaningful internal funding. Rather it reflects aggressive R\&D investments which are expensed in the current year but pay off only in the long run. Nevertheless, high-growth firms do on average enjoy persistently high market-to-book ratios. It is also clear that large cash holdings (26.4\% of total assets for the fastest growing firms) are stockpiled through heavy issuance of new equity (at $8.3 \%$ of total assets annually). It seems that the equity market enables high-growth firms to invest relentlessly in $R \& D$ perhaps for multi-year investment plans and hence allows them to hold cash (Wu and Au Yeung [2011, 2012]).

The results shown earlier in Panel C and D of Table 1 contain important information about growth-type-compatible investment style and financing behavior. The Initial-AI quintile sorts are able to produce monotonic patterns in matched investment style and financing behavior. Column “(3)-(2)” of Panel D shows that the external financing differential, EFD, defined as net equity minus net debt, increases on average from $-0.6 \%$ to $7.0 \%$ annually, and at the same time, the proportion of $R \& D$ in total investment, $R \& D /(R \& D+C a p e x)$, or Investyle, which we use as a measure for investment style, increases from $9.1 \%$ to $39.2 \%$. In short, more intangible investment induces more equity than debt issues in external finance.

These results provide prima facie evidence for growth type compatibility in corporate finance. The patterns are similar to those shown with the three growth types in $\mathrm{Wu}$ and $\mathrm{Au}$ Yeung (2011, 2012). The new variable AI, however, allows finer distinctions among growth types, and its rank correlation with Investyle is as high as 0.45, as shown in Panel C of Table 2. This link underlies growth-type-aligned fundamental patterns. 


\section{Persistence in Investment Style and Financing Behavior}

In this section we investigate to what extent AI and Investyle persist and how financing behaves in a manner compatible with growth type as market conditions change.

Table 3 shows a transition matrix for AI and Investyle. As shown in Panel A, firms in extreme Initial-AI quintiles have a high probability of staying in those same quintiles over time. For example, when re-sorting firms using an updated AI each calendar year, $45 \%$ of the firms in the lowest initial quintile (Low) stay in the lowest quintile, $28 \%$ move up to the next quintile, but only $16 \%, 8 \%$ and $3 \%$ move up further. Firms in the highest initial quintile (High) show even stronger persistence: $64 \%$ stay and $20 \%$ move down to the next AI quintile, but only $9 \%$, 5\% and $2 \%$ move down further. Because of this persistence in AI, Initial AI is able to capture distinct growth types early on. If growth type drives fundamental differences, Initial AI can do a good job as an indicator.

As shown in Panel B of Table 3, although we cannot sort firms into quintiles according to Investyle, because too many firms report zero R\&D (for example, they initially account for 52\% of the total sample), we form five Investyle firms this way: group 1 (Low) contains the zeroR\&D firms and the remaining firms are sorted according to Investyle into quarters (group 2 group 5, High). Investyle also shows strong persistence. For example, 95\% of firms in the lowest Initial-Investyle group (Low) stay there and 73\% of firms in the highest Initial group (High) do likewise. In effect, there is a strong diagonal effect in the Investyle transition matrix of Investyle, with much higher probabilities of staying than migrating.

How firms finance investment is one of the main concerns in corporate finance. How capital investment responds to cash flow is an important part of firm financing behavior which is often traditionally described using Myers’ (1984) pecking order in financing: first retained 
earnings, then debt, and finally new equity as a last resort. The whole idea of financial constraint is based on the premise of a positive differential between the cost of external and internal finance—a wedge reflecting what is called "lemons premium"—due to asymmetric information that adversely affects external financing costs. But Fama and French $(2002,2005)$ find that all kinds of firms issue new equity too frequently to be consistent with this classic pecking order. They suggest several ways in which equity issues get around asymmetric informational imperfections deemed to especially affect equity issues adversely.

The generalization of the classic model of Myers and Majluf (1984) in Wu and Wang (2005) further sheds new light theoretically: while the type of asymmetric information about assets-in-place can dominate and create the classic Myers-Majluf adverse selection effect, an increase in the type of asymmetric information about growth opportunities as market conditions improve can even reverse adverse selection announcement discounts. One implication is that despite big information gaps, high growth firms can use new equity as a natural curb on banks' rent extraction, about which the information production argument for monitored debt or bank financing has been silent (Wu, Sercu and Yao [2009]). Thus, the type of asymmetric information (about assets-inplace versus growth) matters to the financing pecking order.

Table 4 reports how Investyle (the growth-type-aligned investment style) predicts the pecking order under dynamic market conditions. We define the pecking order in financing as the equity and debt financing differential, or External Finance Differential, EFD, as already shown in column "(3)-(2)" of Panel D of Table 1. Here we are regressing EFD on a host of explanatory variables. The two main variables are market-to-book ratio (as a proxy for investment opportunities or market conditions) and its interaction term with Investyle, which also enters separately. Other control variables are Tangibility, E/A (profitability), and LnA (firm size). 
We use three regression specifications. The first regression (1) is just a pooled OLS. The second (2) is also an OLS, but we replace the time-varying annual Investyle with initial Investyle, a time-invariant variable identified early on in a firm's public life. If the main results of the two regressions are qualitatively similar, reverse causation whereby Investyle responds to opportunistic financing behavior is unlikely. The third regression (3) includes firm fixed effects and evaluates within-firm behavior.

As shown in Table 4, the slope estimates for M/B are reliably positive in all three regressions. This means when investment opportunities rise or market conditions improve, corporate investment increases in general and external finance, especially more equity than debt finance, follows. This is consistent with the findings in Fama and French (2002, 2005) that all kinds of firms issue new equity frequently. But not all kinds of firms can easily tap into debt financing. For one thing, firms with many growth options tend to avoid debt financing because of debt overhang concerns (Myers [1977]). This does not mean they have no way out, though.

As expected, the slope estimates for the interaction term $\mathrm{M} / \mathrm{B}^{*}$ Investyle are significantly positive-around 0.009 with $t$-values greater than 8.00 everywhere. This means that the sensitivity of EFD to M/B increases with growth-type-aligned investment style, Investyle. Since EFD, as already shown in column “(3)-(2)” of Panel D of Table 1, is negative for low-growth type but positive for high-growth type firms, its positive sensitivity to $\mathrm{M} / \mathrm{B}$ *Investyle reflects a growth-type-compatible pecking order of financing. This suggests that it is the investment style with more intensive $R \& D$ that tilts firms towards more equity than debt finance when investment opportunities increase or market conditions improve.

How do we know reverse causation is unlikely? Regression (2) uses time-invariant Initial Investyle instead of the time-varying annual Investyle. As shown in Table 4, the slope estimate 
for $\mathrm{M} / \mathrm{B}^{*}$ Investyle and even the $t$-value hardly change-from 0.0090 ( $t$-value=10.73) in regression (1) to 0.0094 ( $t$-value $=10.42)$ in $(2)$. This is not surprising because, as shown in the transition matrix in Panel B of Table 3, Investyle is strongly persistent. But the finding has a profound implication: financing behavior in the future is determined early on. ${ }^{3}$ In regression (3) with firm fixed effects, the similarly significant and positive slope for $\mathrm{M} / \mathrm{B}^{*}$ Investyle indicates that financing behavior under dynamic market conditions arises from within-firm variation. Persistence in a firm's financing behavior is consistent with growth-type-compatible investment and financing based on firm fundamentals.

\section{A Growth Type Explanation for ICFS}

The sensitivity of capital investment to cash flow, ICFS, also tells about financing behavior, and we have shown that financing behavior is related to growth type. We will now show that ICFS itself is robustly related to growth type. We start with examining individual quintiles based on a particular sort (Section V.A). Then we investigate how growth type affects ICFS controlling for potential financing constraints (Section V.B). Finally, we provide robustness checks (Section V.C).

\section{A. ICFS by Quintile}

\footnotetext{
${ }^{3}$ Brown, Fazzari and Petersen (2009) suggest that shifts in the supply of equity finance have driven much of the 1990s R\&D boom and imply that non-fundamentals may cause the supply shifts. Fama and French (2004) also acknowledge a downward shift in equity supply curve since the late 1970s, but point out fundamental changes at the same time-changes in firm characteristics of new lists skewed toward high growth. We take the stand that appropriate financing behavior in response to specific investment style is a first-order concern to firms and that financing per se can hardly create desired investment style.
} 
Panel A of Table 5 reports a monotonic negative relation between ICFS and Initial-AI quartiles using standard investment regressions. Firms in the lowest Initial-AI quintile (Low) have the greatest ICFS (0.370) and firms in the highest Initial-AI quintile (High) have the least ICFS (0.074). The monotonic negative relation persists when firm fixed effects are included (ICFS of 0.297 for quintile 1 and 0.041 for quintile 5). To the extent that Initial AI is a proxy for growth type, the differences in the ICFS estimates suggest that low-growth type firms have a high ICFS and high-growth type firms have a low ICFS.

Note the drastic increase in $\mathrm{R}^{2}$ with firm fixed effects for all quintiles, for example, from 0.12 to 0.49 for quintile 1 . This indicates a great deal of unexplained cross-sectional variation in capital investment.

Since the KZ, WW and SA indexes-often used in the literature in the context of measuring financial constraints_-summarize firm characteristics that are important for corporate finance, we also report the unconditional relationship between ICFS and each index. For each index, quintiles are sorted according to the within-firm, time-series medians of the index. This exercise is intended to give some sense of whether and how robustly ICFS estimates are related to what those previous studies interpret as financial constraints using a large panel dataset.

Panel B of Table 5 shows that the ICFS estimates monotonically increase from KZ quintile $1(0.111)$ to $5(0.288)$; the regression with firm fixed effects also shows a similar pattern. This positive relationship is consistent with a financial constraint explanation for ICFS. Perhaps because it is others (Lamont, Polk and Saa-Requejo [2001]) rather than Kaplan and Zingales (1997, 2000) that construct the KZ index and the latter's original work actually challenges the financial constraint interpretation of ICFS, Baker, Stein and Wurgler (2003) play down the financial constraints interpretation of the $\mathrm{KZ}$ index even though they find a positive relation 
between the ICFS and the $\mathrm{KZ}$ index as well. Instead, they interpret the $\mathrm{KZ}$ index as "equity dependence” and focus on the $\mathrm{KZ}$ index and the slope estimates for $\mathrm{Q}$ in standard investment regressions.

Panel B of Table 5 shows that slope estimates for Q vary with the KZ quintiles in a clear monotonic order, with or without firm fixed effects. For example, with firm fixed effect, the slopes for Q monotonically increase from KZ quintile $1(0.008)$ to 5 (0.051). These results are consistent with the findings in Baker, Stein and Wurgler (2003) to the effect that corporate investment by high $\mathrm{KZ}$ index firms is more sensitive to stock prices than that by low $\mathrm{KZ}$ index firms. According to an earlier study by Barro (1990), financial variables that imbed market prices play a positive role in facilitating investment. Baker, Stein and Wurgler (2003) suggest that this market channel helps the equity dependant firms solve the underinvestment problem because of non-fundamental movements in stock prices in the firms' favor. Regardless of the interpretation of the index, if the ICFS is shown to be related to growth type after controlling for the $\mathrm{KZ}$ index, we will have a cleaner growth type story.

Panel C of Table 5 shows that ICFS estimates monotonically decrease from WW quintile $1(0.402)$ to 5 (0.082). So greater financial constraint in terms of a higher WW index predicts a lower ICFS estimate-a pattern inconsistent with the interpretation of ICFS as a measure of financial constraints.

Whited and Wu (2006) propose the WW index to study systematic risk associated with financial constraints in the context of asset pricing. Hennessy, Levy and Whited (2007) subsequently treat the WW index as a proxy for financial constraints in their corporate finance study. But Hennessy and Whited (2007) conclude that the KZ and WW indexes are better 
proxies for a firm's need of external financing than for its cost of external finance. We simply treat the WW index as a control variable in this study.

Since the SA index is very highly correlated with the WW index (with a correlation coefficient of at least 0.85 as shown in Table 2), the monotonic patterns in Panel D of Table 5 resemble those in Panel C. In view of fundamental differences in the construction of the two indexes, their strong statistical similarity is a bit surprising. The WW index comes from structural model fitting, but like the KZ index, the SA index requires qualitative interpretation of financial constraints in the first place based on annual corporate financial statements. Unless the financial statements contain little information beyond that obviously contained in corporate variables reported in Compustat, the SA index-which is meant to have a more comprehensive coverage than the $\mathrm{KZ}$ index—should have a better sense of financial constraints.

The KZ index, the WW index and the SA index, each with its own index construction, jointly provide a comprehensive set of control variables for the main investment regressions that follow.

\section{B. ICFS and Growth Type}

In standard regressions of capital investment on lagged cash flow and Q, we add the timeinvariant variables, Initial AI, the within-firm median $\mathrm{KZ}$ index, the median $\mathrm{WW}$ index, and the median SA index. More important, these time-invariant variables also enter as interaction terms with lagged cash flow as well as with lagged Q. We use eight regression specifications. In the first four we include one by one the time-invariant variables. In the next three, we include Initial AI and, one by one the financial constraints indexes. Regression (8) includes all the variables together. 
We start by examining the slopes for the time-invariant explanatory variables themselves. As shown in Panel A of Table 6, the slope estimates for Initial AI are significantly negative in all regressions. For example, the slope estimate in regression (8) is -0.021 with a $t$-value of -5.28 . This means low-growth type firms have high capital investment and high-growth type firms have low capital investment, controlling for other explanatory variables.

Panel A also shows that the slope estimates for the median $\mathrm{KZ}$ index, $\mathrm{KZ}_{\text {med}}$, are significant and positive everywhere, for example, $0.176(t$-value $=54.85)$ in regression $(8)$. The slope estimates for $\mathrm{WW}_{\text {med }}$ and $\mathrm{SA}_{\text {med }}$ are also significant and positive everywhere, except that the slope estimate for $\mathrm{WW}_{\text {med }}$ flips to a significantly negative value $(-0.028, t$-value $=-4.18)$ in regression (8) when all variables are present.

The slope estimates for the interaction terms are actually our main focus. In Panel A of Table 6, the slope estimates for Initial AI interacted with cash flow are significantly negative. For example, the slope estimate for $\mathrm{CF} / \mathrm{A}^{*}$ Initial AI in regression (8) is -0.034 with $t$-value of -16.32. While the slope estimates for CF/A, or baseline ICFS, are always positive and significant (consistent with the findings of previous studies using standard investment regressions), the interaction term shows that ICFS either increases or decreases with other factors.

The decrease of ICFS with Initial AI suggests that capital investment by low-growth type firms is highly sensitive to cash flow whereas capital investment by high-growth type firms is less sensitive. In view of higher capital investment in low-growth than high-growth type firms, it is not surprising that internal cash flow is much more important for capital investment in low- 
growth firms than in high-growth firms. This implies more growth-type-compatible investment and financing rather than financial constraint.

Consider now the KZ control. As Panel A of Table 6 shows, the slope estimates for $\mathrm{CF} / \mathrm{A}^{*} \mathrm{KZ}_{\mathrm{med}}$ are positive and significant, for example, 0.067 (t-value=29.13) in regression (8). In view of the positive slopes for $K Z_{\text {med }}$ as shown previously, the positive slope for $C F / A * K Z_{\text {med }}$ indicates that high $\mathrm{KZ}$ firms start with high capital investment which becomes more sensitive to cash flow whereas low KZ firms start with low capital investment which becomes less sensitive to cash flow. Like Initial AI, the $\mathrm{KZ}$ index seems to capture the fact that internal fund is more important for capital investment. But the interpretation of the index is not as straightforward as Initial AI.

The KZ index has a leverage ratio imbedded. High leverage, likely as an outcome, not only reflects a firm's heavy reliance on internal cash flow and debt but also can indicate a debt overhang-pointing to being financially constrained in a conventional sense. This means that the $\mathrm{KZ}$ index is likely to index a mixture of growth type and financial constraint.

Complicating its interpretation, the KZ index can be also interpreted as indicating "equity dependence” instead of financial constraint (Baker, Stein and Wurgler [2003]). Departing from the traditional focus on ICFS, Baker, Stein and Wurgler (2003) use the sensitivity of corporate investment to stock prices in standard investment regressions to measure equity dependence.

We start with the baseline case of the slope estimates for Q. Panel A of Table 6 shows these estimates to be positive and significant everywhere. This is consistent with the essence of Q theory-that an increase in investment opportunities induces more new investment, even though one uses market-to-book ratio as a noisy proxy for Q. Most researchers have no problem 
with this baseline intuition, but many have been baffled by various plausible effects on this fundamental relation.

Panel A shows that the Q sensitivity always decreases with Initial AI. For example, the slope estimate for $\mathrm{Q}^{*}$ Initial $\mathrm{AI}$ is -0.21 ( $t$-value $=-10.69$ ) in regression (8). This means capital investment by high and low growth firms has low and high sensitivity to Q, respectively.

In contrast, a greater KZ index always predicts a significantly greater Q sensitivity. For example, the slope estimate for $\mathrm{Q}^{*} \mathrm{KZ}_{\text {med }}$ is $0.065(t$-value $=24.35)$ in regression $(8)$. This means capital investment by high and low KZ firms has high and low sensitivity to Q, respectively. To the extent that $\mathrm{KZ}$ measures equity dependence, these relationships would predict that high equity dependent firms have high levels of capital investment when investment opportunities increase or market conditions improve but less equity dependent firms should be less responsive to such conditions. Baker, Stein and Wurgler (2003) interpret high Q sensitivity as an indication of being sensitive to non-fundamental movements in stock prices. Since Initial AI and the KZ show opposite results here, the equity dependence interpretation would suggest that capital investment by high-growth type firms is less influenced by non-fundamental movements.

The sensitivity of investment to cash flow as well as to Q reflects financing behavior which should be better judged with respect to within-firm financing patterns. Panel B of Table 6 reports the results with firm fixed effects included. All the results are qualitatively the same as in Panel A. For example, in regression (8) in which all controlling explanatory variables are present, the slope estimate for $\mathrm{CF} / \mathrm{A}^{*}$ Initial $\mathrm{AI}$ is -0.042 ( $t$-value $=-14.47$ ), and for $\mathrm{Q}^{*}$ Initial $\mathrm{AI}$ is -0.014 ( $t$-value $=-6.30)$. So the main results still hold: capital investment by high-growth type firms has low sensitivity to cash flow as well as Q, but the sensitivity for low-growth type firms is high. 
The WW and SA controls confirm that ICFS is unlikely due to financial constraints. As shown in Table 2, the two indexes both have modestly positive correlation with Initial AI. They may therefore contain information about growth type as well. Like Initial AI, both the WW and SA indexes negatively predict the ICFS, as shown in Panels A and B of Table 6. For example, the slope estimate for $\mathrm{CF} / \mathrm{A} * \mathrm{WW}_{\text {med }}$ is $-0.133(t$-value $=-36.66)$ in regression (6) and for $\mathrm{CF} / \mathrm{A}^{*} \mathrm{SA}_{\text {med }}$ is -0.108 ( $t$-value $\left.=-33.22\right)$ in regression $(7)$ in Panel A. These findings would suggest that firms with high and low degrees of financial constraints have low and high ICFS, respectively. So either the ICFS does not measure the degree of financial constraints or the WW and SA indexes indicate something else.

Hennessy, Levy and Whited (2007) treat the WW index as a proxy for financial constraints but Hennessy and Whited (2007) suggest at the same time that both the KZ and WW indexes can be better proxies for a firm's need of external financing than for its cost of external finance. Panels A and B of Table 6 show that like the KZ index, both the WW and SA indexes positively predict Q sensitivity. For example, the slope estimate for $\mathrm{Q}^{*} \mathrm{WW}$ med is 0.060 ( $t$-value $=18.06)$ in regression (6) and for $\mathrm{Q}^{*} \mathrm{SA}_{\text {med }}$ is 0.039 ( $t$-value $\left.=12.48\right)$ in regression $(7)$ in Panel A. The equity dependence logic would suggest that high and low WW or SA firms are highly and weakly equity dependent firms. But unlike the KZ and Initial-AI firms, the WW and SA firms both have opposite sensitivities to cash flow and Q. In short, Initial AI contains significant information beyond that contained in the WW and SA indexes as well.

The results for Initial AI support our growth type explanation for ICFS. The ICFS decreases with firm growth type identified by Initial AI. One may argue that Initial AI measures financial constraints in reverse order: high-growth type firms are less financially constrained and low-growth type firms are more financially constrained. But such an explanation for financial 
constraints is apparently inconsistent with the concept of financial constraint closely related to the general idea of informational imperfection, because it implies that the degree of financial constraints is low for high-growth type firms which should face a great deal of uncertainty in general.

Perhaps the KZ, WW and SA indexes all contain significant information beyond that about financial constraints. Our concern, however, is whether they contain sufficient information on growth type to potentially wash out any predictive power of Initial AI. It turns out that the controlled tests reported in Table 6 show they do not. In addition, unlike Initial AI, the KZ, WW and SA indexes all tend to affect Q sensitivity positively. In short, whatever the three indexes measure, Initial AI has significant additional information about growth type. The indexes are typically presented as a basket of corporate variables and their inclusion in regressions may attenuate the growth type effect of Initial AI.

Our growth type compatibility view suggests that optimal financing arrangements follow investment style in a manner compatible with growth type. Firms with investment style of more R\&D intensity (higher Investyle) tend to be of higher growth type (higher Initial AI) and are expected to rely less on internal funding but more on external finance, especially equity financing. This is the pattern in Panel D of Table 1, and it is more pronounced when investment opportunities rise or market conditions improve, as shown in Table 4. As a result, high- and lowgrowth type firms naturally have low and high ICFS, consistent with a growth-type-aligned pecking order in financing.

\section{Robustness Check}

Replacing Initial AI with time-varying Investyle provides a clear sense of growth-type-related firm fundamentals. We also let the KZ, WW and SA indexes vary with time. Growth type 
compatibility predicts that distinct growth types will be locked together with distinct investment styles and optimal financing behavior in response. If ICFS really reflects firm-type-determined financing behavior, a persistent variable like Investyle, despite its time variation, should still capture any genuine relationship between growth type and the ICFS.

And in fact the results for Investyle in Table 7 are qualitatively the same as those for Initial AI in Table 6. As shown in Panel A, for example, in regression (8), the slope estimate for $\mathrm{CF} / \mathrm{A} *$ Investyle is -0.099 ( $t$-value $=-42.30)$, and for $\mathrm{Q}^{*}$ Investyle it is -0.078 ( $t$-value $\left.=-30.58\right)$. When firm fixed effect is included, as shown in Panel B, again in regression (8), the slope estimate for CF/A*Investyle is -0.087 ( $t$-value $=-34.02)$ and for $\mathrm{Q}^{*}$ Investyle it is $-0.093(t$ value $=-34.04)$. At the same time, the results for the three index control variables also remain similar to those in Table 6. So even with controls for well-known financial constraint variables, high and low Investyle firms have low and high ICFS estimates, as expected.

With a clear sense of firm fundamentals, the results based on Investyle strongly support our growth type explanation for ICFS.

\section{Conclusions}

We show that there is a monotonic negative relationship between the sensitivity of investment to cash flow (ICFS) and firm growth type. This is evidence for the ability of growth-typecompatible investment and financing to mitigate informational imperfections and allow firms to grow on distinct growth paths compatible with their growth types.

One may argue that the monotonic negative relation between ICFS and growth type simply means that the low-growth type firms are more financially constrained. But this interpretation immediately has trouble with the fact that they typically have access to all three 
financing sources and are solid dividend payers. On the other hand, the negative relation may mean that the high-growth type firms are less financially constrained. But if this interpretation is true, one should accept that asymmetric informational imperfections do not prevent the highgrowth type firms from investing and growing despite a great deal of uncertainty.

This is not to suggest that financial constraints do not exist. For example, some firms obviously have financial constraints due to government regulation. But one should wonder why researchers have had difficulty identifying financial constraints among listed firms in general. Consistent with neoclassical intuition, the results of this study suggest that for firms listed on well-functioning capital markets, corporate investment is resilient to informational imperfections. 


\section{References}

Almeida, Heitor, and Murillo Campello, 2007, Financial constraints, asset tangibility, and corporate investment, Review of Financial Studies 20, 1429-1460.

Almeida, Heitor, Murillo Campello, and Michael Weisbach, 2004, The cash flow sensitivity of cash, Journal of Finance 59, 1777-1804.

Alti, Aydogan, 2003, How sensitive is investment to cash flow when financing is frictionless? Journal of Finance 58, 707-722.

Baker, Malcolm, Jeremy Stein, and Jeffrey Wurgler, 2003, When does the market matter? Stock prices and the investment of equity-dependent firms, Quarterly Journal of Economics 118, 969-1005.

Barro, Robert, 1990, The stock market and investment, Review of Financial Studies 3, 115-132.

Brown, J., Fazzari, S., Petersen, B., 2009. Financing innovation and growth: cash flow, external equity, and the 1990s R\&D boom. Journal of Finance 64, 151-185.

Cao, C., Simin, T., Zhao, J., 2008. Can growth options explain the trend in idiosyncratic risk? Review of Financial Studies 21, 2599-2633.

Cleary, Sean, 1999, The relationship between firm investment and financial status, Journal of Finance 54, 673-692.

Cooney, Jr John W., and Avner Kalay, 1993, Positive information from equity issue announcements, Journal of Financial Economics 33, 149-172.

Erickson, Timothy, and Toni Whited, 2000, Measurement effort and the relationship between investment and q, Journal of Political Economy 108, 1027-1057.

Fama, Eugene F., and Kenneth R. French, 2001. Disappearing dividends: changing firm characteristics or lower propensity to pay? Journal of Financial Economics 60, 3-44.

Fama, Eugene F., and Kenneth R. French, 2002, Testing trade-off and pecking order predictions about dividends and debt, Review of Financial Studies 15, 1-33.

Fama, Eugene F., and Kenneth R. French, 2004. New lists: fundamentals and survival rates. Journal of Financial Economics 73, 229-269.

Fama, Eugene F., and Kenneth R. French, 2005, Financing decisions: Who issues stock? Journal of Financial Economics 76, 549-582. 
Fazzari, Steven, Glenn Hubbard, and Bruce Petersen, 1988, Financing constraints and corporate investment, Brookings Papers on Economic Activity 1, 141-195.

Fazzari, Steven, Glenn Hubbard, and Bruce Petersen, 2000, Investment-cash flow sensitivities are useful: A comment on Kaplan and Zingales, Quarterly Journal of Economics 115, 695-705.

Gan, Jie, 2007, Collateral, debt capacity, and corporate investment: Evidence from a natural experiment, Journal of Financial Economics 85, 709-734.

Gomes, Joao, 2001, Financing investment, American Economic Review 91, 1263-1285.

Hadlock, Charles and Joshua Pierce, 2010, New evidence on measuring financial constraints: moving beyond the KZ index, Review of Financial Studies 23, 1909-1940.

Hennessy, Christopher, Amnon Levy, and Toni Whited, 2007, Testing Q theory with financing frictions, Journal of Financial Economics 83, 691-717.

Hennessy, Christopher, and Toni Whited, 2007, How costly is external financing? Evidence from a structural estimation, Journal of Finance 62, 1705-1745.

Hubbard, R. Glenn, 1998, Capital-market imperfections and investment, Journal of Economic Literature 36, 193-225.

Kaplan, Steven, and Luigi Zingales, 1997, Do investment-cashflow sensitivities provide useful measures of financing constraints? Quarterly Journal of Economics 112, 169-215.

Kaplan, Steven, and Luigi Zingales, 2000, Investment-cash flow sensitivities are not valid measures of financing constraints, Quarterly Journal of Economics 115, 707-712.

Lamont, Owen, Christopher Polk, and Jesus Saa-Reguejo, 2001, Financial constraints and stock returns, Review of Financial Studies 14, 529-554.

McLean, David R., 2011, Share issuance and cash savings, Journal of Financial Economics 99, 693-715.

Mikkelson, Wayne, and Megan Partch, 2003, Do persistent large cash reserves hinder performance? Journal of Financial and Quantitative Analysis 38, No. 2, 275-294.

Moyen, Nathalie, 2004, Investment-cash flow sensitivities: Constrained versus unconstrained firms, Journal of Finance 59, 2061-2092.

Myers, Stewart C., 1977, Determinants of corporate borrowing, Journal of Financial Economics $5,147-175$.

Myers, Stewart C., 1984, The capital structure puzzle, Journal of Finance 39, 575-592. 
Myers, Stewart C., 2003, Financing of corporations, in George Constantinides, Milton Harris, and Rene Stulz, eds.: North-Holland Handbooks of Economics of Finance (Elsevier, Amsterdam, The Netherlands).

Myers, Stewart C., and Nicholas S. Majluf, 1984, Corporate financing and investment decisions when firms have information that investors do not have, Journal of Financial Economics 13, 187-221.

Pastor, Lubos and Piertro Veronesi, 2003, Stock valuation and learning about profitability, Journal of Finance 58, 1749-1789.

Pastor, Lubos, and Pietro Veronesi, 2005, Rational IPO waves, Journal of Finance 60, 17131757.

Rajan, Raghuram G., and Luigi Zingales, 1995, What do we know about capital structure? Some evidence from international data, Journal of Finance 50, 1421-1460.

Stein, Jeremy C., 1996, Rational capital budgeting in an irrational world, Journal of Business 69, 429-455.

Whited, Toni, and Guojun Wu, 2006, Financial constraints risk, Review of Financial Studies 19, 531-559.

Wu, Xueping, and Chau Kin Au Yeung, 2011, A growth-type explanation for persistence in retained earnings and the decision to pay dividends, Working paper, City University of Hong Kong.

Wu, Xueping, and Chau Kin Au Yeung, 2012, Firm growth type and capital structure persistence, Journal of Banking and Finance, Forthcoming.

Welch, Ivo, 2004, Capital structure and stock returns, Journal of Political Economy 112, 106-131.

Wu, Xueping, and Zheng Wang, 2005, Equity financing in a Myers-Majluf framework with private benefits of control, Journal of Corporate Finance 11, 915-945.

Wu, Xueping, Piet Sercu, and Jun Yao, 2009, Does competition from new equity mitigate bank rent extraction? Insights from Japanese data, Journal of Banking and Finance 33, No. 11, 1884-1897.

Zingales, Luigi, 2000, In search of new foundations, Journal of Finance 55, 1623-1653. 
Appendix: Definition of Annual Variables

\begin{tabular}{|c|c|}
\hline Variable & Definition \\
\hline $\mathrm{AI}_{\mathrm{t}}$ & Within-firm monthly standard deviation of M/B \\
\hline $\mathrm{M} / \mathrm{B}_{\mathrm{t}}$ & $\begin{array}{l}\text { [Market Equity + Total Debt (Compustat items: } 34+9)+ \text { Preferred Stock (10) } \\
\text { - Deferred Tax (35)] / Asset }(6) ;\end{array}$ \\
\hline Market Equity & CRSP’s Closing Price (Prc)*Shares Outstanding (Shrout) \\
\hline Tangibility $_{\mathrm{t}}$ & [Inventories (3) + Property, Plant and Equipment (8)] / Asset $_{t}(6)$ \\
\hline Leverage $_{t}$ & [Short-term Debt (34) + Long-term Debt (9)] / Asset $_{t}(6)$ \\
\hline \%Payers ${ }_{t}$ & $\begin{array}{l}\text { The proportion of payers in year } t \text {, where a payer dummy takes } 1 \text { if dividends } \\
\text { per share by the ex date (26) are non-zero; otherwise, it takes } 0 \text {. }\end{array}$ \\
\hline $\operatorname{Ln}_{t}$ & Log of Asset $_{t}(6)$ \\
\hline Age $_{t}$ & The number of years since a firm was listed \\
\hline Capex/ $A_{t}$ & Capital Expenditure (128) / Asset $_{t}(6)$ \\
\hline $\mathrm{R} \& \mathrm{D} / \mathrm{A}_{\mathrm{t}}$ & R\&D (46) / Asset $t$ (6) (A missing value for R\&D is replaced by zero.) \\
\hline$\Delta \mathrm{A} / \mathrm{A}_{\mathrm{t}}$ & Change in Asset (6) from year $t-1$ to year $t /$ Asset $_{t}(6)$ \\
\hline$\Delta \mathrm{S} / \mathrm{S}_{\mathrm{t}}$ & Change in Sales (12) from year $t-1$ to year $t /$ Sales $_{t}(12)$ \\
\hline $\mathrm{E} / \mathrm{A}_{\mathrm{t}}$ & $\begin{array}{l}\text { [Earnings Before Extraordinary Items (18) + Interest Expense (15) + Income } \\
\text { Statement Deferred Taxes (50) if available] / Asset } t_{t}(6)\end{array}$ \\
\hline $\mathrm{CF} / \mathrm{A}_{\mathrm{t}}$ & $\begin{array}{l}\text { [Depreciation and Amortization (14) + Earnings Before Extraordinary Items } \\
(18)] / \text { Asset }_{t}(6)\end{array}$ \\
\hline Cash/ $\mathrm{A}_{\mathrm{t}}$ & Cash (1) / Asset $_{t}(6)$ \\
\hline$\Delta \mathrm{RE} / \mathrm{A}_{\mathrm{t}}$ & Change in Retained Earnings (36) from year $t-1$ to year $t$ / Asset $t_{t}(6)$ \\
\hline$\Delta$ Debt/A $A_{t}$ & Net Debt Issue $(111-114) /$ Asset $_{t}(6)$ \\
\hline$\Delta$ Equity/A & Net Equity Issue $(108-115) /$ Asset $_{t}(6)$ \\
\hline $\mathrm{EFD}_{\mathrm{t}}$ & External Finance Differential: $\Delta$ Equity/ $\mathrm{A}_{t}-\Delta \mathrm{Debt} / \mathrm{A}_{\mathrm{t}}$ \\
\hline Investyle $_{t}$ & $R \& D_{t}(46) /\left[R \& D_{t}(46)+\right.$ Capital Expenditures or Capex $\left.(128)\right]$ \\
\hline $\mathrm{Q}_{\mathrm{t}}$ & $\begin{array}{l}\text { [Market Equity + Asset (6) - Common Equity (60) - Deferred Taxes (74)] / } \\
\text { Asset }_{t}(6)\end{array}$ \\
\hline
\end{tabular}


Table 1: $\quad$ Firm Variables for Each Initial-AI Quintile

This table reports annual average values of corporate finance variables for each initial-growth-type-sorted firm quintile or Initial-AI quintile. These reported variables stand for growth type characteristics (Panel A), indexes and some characteristics for financial constraints (Panel B), investment, growth in assets and sales, and profitability profile (Panel C), and cash flow, cash holdings, financing arrangement, and investment style (Panel D). Asymmetric information (AI) refers to the standard deviation of monthly firm market-to-book ratio, where the variation comes mostly from 12 monthly firm market values for a firm's annual variable. A firm's AI represents its growth type. Initial AI is the time-series average of AI over year 0,1 and 2, where year 0 is the first year of a firm's data report in the total sample. The Initial growth type quintiles are based on a single cross-firm sort on Initial AI. Alternatively, a two-way sort on initial annual market-to-book ratio (M/B) and initial asset tangibility or collaterals (Tangibility) is used to generate three groups with low- (G1), mixed- (G2) and high-growth (G3). The annual average value for G1, G2 or G3 means the percent of G1, G2 or G3 firms in each Initial-AI quintile. The annual average value for $\mathrm{AI}$, the $\mathrm{KZ}$ index, the WW index, the SA index, and each of the other variables is calculated using the Fama-MacBeth method, namely, a cross-firm average within each Initial-AI quintile each year followed by a time-series average of the annual averages over the sample period. Investyle $\mathrm{t}_{\mathrm{t}}$ refers to $\mathrm{R} \& \mathrm{D} /($ Capex $+\mathrm{R} \& \mathrm{D})$, a proxy for investment style. The variables are defined in Appendix. The sample period is from 1971 to 2006.

\begin{tabular}{lrrrrrrr}
\hline & \multicolumn{7}{c}{ Panel A: Growth Type Characteristics } \\
\hline Initial AI & No. of Firms & $\mathrm{AI}_{\mathrm{t}}$ & $\mathrm{G} 1$ & $\mathrm{G} 2$ & $\mathrm{G} 3$ & $\mathrm{M} / \mathrm{B}_{\mathrm{t}}$ & Tangibility $_{\mathrm{t}}$ \\
\cline { 2 - 8 } 1 Low & 2,484 & 0.07 & $75.4 \%$ & $24.2 \%$ & $0.3 \%$ & 0.82 & 0.60 \\
2 & 2,484 & 0.12 & $48.6 \%$ & $43.8 \%$ & $7.5 \%$ & 1.03 & 0.55 \\
3 & 2,484 & 0.19 & $16.1 \%$ & $48.8 \%$ & $35.2 \%$ & 1.32 & 0.51 \\
4 & 2,484 & 0.34 & $1.1 \%$ & $36.5 \%$ & $62.4 \%$ & 1.91 & 0.44 \\
5 High & 2,484 & 0.60 & $0.0 \%$ & $22.5 \%$ & $77.5 \%$ & 2.77 & 0.39
\end{tabular}

Panel B: Indexes and Some Characteristics for Financial Constraints

\begin{tabular}{|c|c|c|c|c|c|c|c|}
\hline Initial AI & $\mathrm{KZ}_{\mathrm{t}}$ & $\mathrm{WW}_{\mathrm{t}}$ & $\mathrm{SA}_{\mathrm{t}}$ & Leverage $_{t}$ & \%Payers $_{\mathrm{t}}$ & $\operatorname{Ln}_{t}$ & $\mathrm{AGE}_{\mathrm{t}}$ \\
\hline 1 Low & 0.61 & -0.90 & -3.33 & 0.32 & $68.1 \%$ & 19.76 & 13.59 \\
\hline 2 & 0.43 & -0.86 & -3.07 & 0.27 & $51.9 \%$ & 19.03 & 10.63 \\
\hline 3 & 0.17 & -0.83 & -2.89 & 0.23 & $40.0 \%$ & 18.59 & 8.77 \\
\hline 4 & -0.38 & -0.82 & -2.78 & 0.17 & $34.6 \%$ & 18.40 & 7.34 \\
\hline 5 High & -0.71 & -0.80 & -2.68 & 0.14 & $24.6 \%$ & 18.14 & 6.48 \\
\hline
\end{tabular}

Panel C: Investment Style, Asset and Sales Growth, and Profitability Profile

\begin{tabular}{lrrrrrrr} 
Initial AI & \multicolumn{1}{c}{ Capex/能 } & $\mathrm{R} \& \mathrm{D} / \mathrm{A}_{\mathrm{t}}$ & $\Delta \mathrm{A} / \mathrm{A}_{\mathrm{t}}$ & $\Delta \mathrm{S} / \mathrm{S}_{\mathrm{t}}$ & $\mathrm{E} / \mathrm{A}_{\mathrm{t}}$ & $\mathrm{E} / \mathrm{A}_{\mathrm{t}}<0$ & $\mathrm{E} / \mathrm{A}_{\mathrm{t}}>0$ \\
\cline { 2 - 8 } 1 Low & $6.6 \%$ & $0.7 \%$ & $10.1 \%$ & $11.2 \%$ & $12.1 \%$ & $-6.1 \%$ & $12.9 \%$ \\
2 & $7.5 \%$ & $1.4 \%$ & $15.2 \%$ & $15.1 \%$ & $13.6 \%$ & $-7.4 \%$ & $14.8 \%$ \\
3 & $8.2 \%$ & $2.5 \%$ & $22.1 \%$ & $20.7 \%$ & $13.6 \%$ & $-10.2 \%$ & $16.0 \%$ \\
4 & $8.1 \%$ & $5.5 \%$ & $29.9 \%$ & $28.0 \%$ & $12.3 \%$ & $-15.4 \%$ & $17.5 \%$ \\
5 High & $7.7 \%$ & $7.5 \%$ & $42.2 \%$ & $40.0 \%$ & $9.9 \%$ & $-17.5 \%$ & $18.5 \%$
\end{tabular}

Panel D: Cash Flow, Cash Holdings, Financing Arrangement, and Investment Style

\begin{tabular}{lrrrrrrr} 
Initial AI & $\mathrm{CF} / \mathrm{A}_{\mathrm{t}}$ & $\mathrm{Cash} / \mathrm{A}_{\mathrm{t}}$ & $(1) \Delta \mathrm{RE} / \mathrm{A}_{\mathrm{t}}$ & $(2) \Delta \mathrm{Debt} / \mathrm{A}_{\mathrm{t}}$ & $(3) \Delta$ Equity/ $_{\mathrm{t}}$ & $(3)-(2)$ & Investyle $_{\mathrm{t}}$ \\
\cline { 2 - 8 } 1 Low & $7.3 \%$ & $6.3 \%$ & $1.1 \%$ & $1.0 \%$ & $0.4 \%$ & $-0.6 \%$ & $9.1 \%$ \\
2 & $8.2 \%$ & $8.3 \%$ & $1.8 \%$ & $1.3 \%$ & $1.2 \%$ & $-0.1 \%$ & $13.6 \%$ \\
3 & $8.1 \%$ & $12.1 \%$ & $1.6 \%$ & $1.5 \%$ & $2.9 \%$ & $1.4 \%$ & $18.3 \%$ \\
4 & $6.5 \%$ & $19.8 \%$ & $0.3 \%$ & $1.3 \%$ & $5.4 \%$ & $4.1 \%$ & $30.5 \%$ \\
5 High & $3.8 \%$ & $26.4 \%$ & $-2.3 \%$ & $1.4 \%$ & $8.3 \%$ & $7.0 \%$ & $39.2 \%$ \\
\hline
\end{tabular}




\section{Table 2: Correlation Matrix}

This table reports the correlation matrix for Initial AI, Initial Investyle, and annual values of AI, Investyle, the KZ index, the WW index and the SA index. For each pair of variables (e.g., AI and KZ), three ways of calculating the correlation coefficient are shown in Panels A, B and C, respectively. The sample period is from 1971 to 2006.

$\begin{array}{lllllll}\text { Initial AI } & \mathrm{AI}_{\mathrm{t}} & \text { Initial Investyle } & \text { Investyle }_{\mathrm{t}} & \mathrm{KZ}_{\mathrm{t}} & \mathrm{WW}_{\mathrm{t}} & \mathrm{SA}_{\mathrm{t}}\end{array}$

Panel A: Cross-firm Correlation Calculated Each Year, Then Time-series Averaged

\begin{tabular}{lrrrrrrrr}
$\mathrm{AI}_{\mathrm{t}}$ & 0.44 & 1.00 & & & & & \\
Initial Investyle Investyle $_{\mathrm{t}}$ & 0.23 & 0.29 & 1.00 & & & & \\
$\mathrm{KZ}_{\mathrm{t}}$ & 0.23 & 0.26 & 0.85 & 1.00 & & & \\
$\mathrm{WW}_{\mathrm{t}}$ & -0.16 & -0.23 & -0.15 & -0.14 & 1.00 & & \\
$\mathrm{SA}_{\mathrm{t}}$ & 0.18 & 0.23 & 0.18 & 0.20 & 0.13 & 1.00 & \\
& 0.20 & 0.29 & 0.18 & 0.18 & 0.00 & 0.86 & 1.00 \\
\hline
\end{tabular}

Panel B: Within-firm Median, Then Cross-firm Correlation of Medians

\begin{tabular}{|c|c|c|c|c|c|c|c|}
\hline $\mathrm{AI}_{\mathrm{t}}$ & 0.34 & 1.00 & & & & & \\
\hline Initial Investyle & 0.22 & 0.48 & 1.00 & & & & \\
\hline Investyle $_{t}$ & 0.23 & 0.49 & 0.90 & 1.00 & & & \\
\hline $\mathrm{KZ}_{\mathrm{t}}$ & -0.11 & -0.28 & -0.25 & -0.25 & 1.00 & & \\
\hline $\mathrm{WW}_{\mathrm{t}}$ & 0.12 & 0.30 & 0.23 & 0.25 & 0.13 & 1.00 & \\
\hline $\mathrm{SA}_{\mathrm{t}}$ & 0.12 & 0.32 & 0.21 & 0.21 & 0.05 & 0.89 & 1.00 \\
\hline \multicolumn{8}{|c|}{ Panel C: Within-firm Medians Ranked, Then Cross-firm Correlation of Ranks } \\
\hline $\mathrm{AI}_{\mathrm{t}}$ & 0.79 & 1.00 & & & & & \\
\hline Initial Investyle & 0.39 & 0.45 & 1.00 & & & & \\
\hline Investyle $_{t}$ & 0.36 & 0.43 & 0.86 & 1.00 & & & \\
\hline $\mathrm{KZ}_{\mathrm{t}}$ & -0.28 & -0.35 & -0.30 & -0.31 & 1.00 & & \\
\hline $\mathrm{WW}_{\mathrm{t}}$ & 0.33 & 0.34 & 0.22 & 0.19 & 0.14 & 1.00 & \\
\hline $\mathrm{SA}_{\mathrm{t}}$ & 0.31 & 0.33 & 0.18 & 0.14 & 0.03 & 0.85 & 1.00 \\
\hline
\end{tabular}


Table 3: Transition Matrix for Annual AI and R\&D/(Capex+R\&D)

This table shows the total frequencies at which a firm in an initial firm group transits to the five annually updated firm groups over time. Panel A is the transition matrix for annual AI, which contains information about growth type. Firms are re-sorted into quintiles according to annual AI each calendar year. Panel B is the transition matrix for $\mathrm{R} \& \mathrm{D} /(\mathrm{Capex}+\mathrm{R} \& \mathrm{D})$, or Investsyle as labeled in Table 1 , as a proxy for investment style. Firms that report zero R\&D initially account for $52 \%$ of the total sample. The zero-R\&D firms are in Investyle group 1 (Low) and the remaining firms which report positive R\&D are sorted into quarters (group 2 - group 5, High) according to Investsyle. The five Investyle firm groups are re-sorted each calendar year. Total frequencies sum up to $100 \%$ (horizontally) across the five updated firm groups. The sample period is 1971-2006.

\begin{tabular}{|c|c|c|c|c|c|}
\hline \multirow[b]{2}{*}{ Initial } & \multicolumn{5}{|c|}{ Panel A: Annually Updated $\mathrm{AI}_{\mathrm{t}}$ or Growth Type } \\
\hline & 1 Low & 2 & 3 & 4 & 5 High \\
\hline 1 Low & $45 \%$ & $28 \%$ & $16 \%$ & $8 \%$ & $3 \%$ \\
\hline 2 & $19 \%$ & $25 \%$ & $26 \%$ & $21 \%$ & $9 \%$ \\
\hline 3 & $9 \%$ & $16 \%$ & $22 \%$ & $27 \%$ & $26 \%$ \\
\hline 4 & $4 \%$ & $9 \%$ & $15 \%$ & $25 \%$ & $47 \%$ \\
\hline \multirow[t]{2}{*}{5 High } & $2 \%$ & $5 \%$ & $9 \%$ & $20 \%$ & $64 \%$ \\
\hline & \multicolumn{5}{|c|}{ Panel B: Annually Updated $R \& D_{t} /\left(\right.$ Capex $\left._{t}+R \& D_{t}\right)$, or Investyle $t_{t}$} \\
\hline Initial & 1 Low & 2 & 3 & 4 & 5 High \\
\hline 1 Low & $95 \%$ & $3 \%$ & $1 \%$ & $1 \%$ & $0 \%$ \\
\hline 2 & $29 \%$ & $42 \%$ & $19 \%$ & $7 \%$ & $3 \%$ \\
\hline 3 & $8 \%$ & $17 \%$ & $33 \%$ & $27 \%$ & $14 \%$ \\
\hline 4 & $5 \%$ & $4 \%$ & $15 \%$ & $31 \%$ & $44 \%$ \\
\hline 5 High & $1 \%$ & $2 \%$ & $6 \%$ & $18 \%$ & $73 \%$ \\
\hline
\end{tabular}


Table 4: Growth-type-aligned Pecking Order in Financing under Dynamic Market Conditions

This table shows results of regressions in which the dependent variable is EFD (= $\Delta$ Equity/ $A_{t}-\Delta$ Debt/ $\left.A_{t}\right)$ and the one-year lagged explanatory variables are market-to-book ratio, $\mathrm{M} / \mathrm{B}$, Investyle $(=\mathrm{R} \& \mathrm{D} /[\mathrm{Capex}+\mathrm{R} \& \mathrm{D}])$, their interaction and other controls. The equity-and-debt, or external financing differential, EFD, measures the pecking order-to what extent that equity dominates over debt in external finance. The interaction between market-to-book ratio, a proxy for market conditions, and Investyle $\mathrm{t}_{-1}$, a proxy for investment in R\&D versus tangibles, captures growth-type-aligned financing behavior under year-by-year dynamic market conditions. Regression (1) is a standard panel regression. Regression (2) replaces annual Investyle in regression (1) with Initial Investyle, where the initial value is defined in the same way as in Initial AI. Regression (3) is regression (1) with firm fixed effects. The sample period is 1971-2006.

\begin{tabular}{|c|c|c|c|c|c|c|}
\hline & \multicolumn{2}{|c|}{ (1) Pooled OLS } & \multicolumn{2}{|c|}{ (2) Initial Investyle } & \multicolumn{2}{|c|}{ (3) Firm Fixed Effect } \\
\hline & Coef. & t-stat & Coef. & t-stat & Coef. & t-stat \\
\hline Intercept & 0.0916 & $(21.14)$ & 0.0934 & $(21.55)$ & & \\
\hline $\mathrm{M} / \mathrm{B}_{\mathrm{t}-1}$ & 0.0189 & $(41.47)$ & 0.0190 & $(40.99)$ & 0.0200 & (32.33) \\
\hline $\mathrm{M} / \mathrm{B}_{\mathrm{t}-1} *$ Investyle $_{\mathrm{t}-1}$ & 0.0090 & $(10.73)$ & 0.0094 & $(10.42)$ & 0.0089 & $(8.02)$ \\
\hline Investyle $_{\mathrm{t}-1}$ & -0.0022 & $(-0.98)$ & -0.0061 & $(-2.44)$ & 0.0147 & (3.33) \\
\hline Tangibility $_{\mathrm{t}-1}$ & 0.0223 & (11.29) & 0.0204 & (10.36) & 0.0510 & $(11.60)$ \\
\hline $\mathrm{E} / \mathrm{A}_{\mathrm{t}-1}$ & -0.2176 & $(-61.46)$ & -0.2201 & $(-62.44)$ & -0.1754 & $(-33.88)$ \\
\hline $\operatorname{LnA}_{t-1}$ & -0.0055 & $(-25.31)$ & -0.0055 & $(-25.28)$ & -0.0096 & $(-17.73)$ \\
\hline Firm-years & & 108,705 & & 108,705 & & 108,705 \\
\hline $\mathrm{R}^{2}$ & & 0.12 & & 0.12 & & 0.29 \\
\hline
\end{tabular}




\section{Table 5: Investment-Cash-Flow-Sensitivity (ICFS) for Each Firm Quintile}

This table reports the results of regressions where the dependent variable is Capex/ $\mathrm{A}_{t}$ (corporate capital investment in year $t$ ) and the explanatory variables are CF/ $\mathrm{A}_{\mathrm{t}-1}$ (cash flow in year $t-1$ ) and $\mathrm{Q}_{\mathrm{t}-1}$ (Tobin's q in year $t-1$, which has a correlation of 0.98 with market-to-book ratio, $\mathrm{M} / \mathrm{B}_{\mathrm{t}-1}$ ). Firm quintiles are sorted based on initial growth type or Initial AI (Panel A), the KZ index time-series median, $\mathrm{KZ}_{\mathrm{med}}(\mathrm{Panel} \mathrm{B}$ ), the WW index timeseries median, $\mathrm{WW}_{\text {med }}$ (Panel C), or the SA index time-series median, $\mathrm{SA}_{\text {med }}$ (Panel D). The left half of the table shows the results from a pooled OLS panel regression for each firm quintile and the right half shows the results with firm-fixed effects. The slope, $b$, for $C F / A_{t-1}$ measures the sensitivity of capital investment to cash flow. The sample period is 1971-2006.

\begin{tabular}{|c|c|c|c|c|c|c|c|c|c|c|c|}
\hline \multirow{3}{*}{$\begin{array}{c}\text { Panel A } \\
\text { Initial AI }\end{array}$} & \multicolumn{6}{|c|}{ Panel A1: Panel Regression for Each Initial AI Quintile } & \multicolumn{5}{|c|}{ Panel A2: With Firm-fixed Effects } \\
\hline & \multirow[b]{2}{*}{ Firm Year } & \multicolumn{2}{|c|}{$\mathrm{CF} / \mathrm{A}_{\mathrm{t}-1}$} & \multicolumn{2}{|c|}{$\mathrm{Q}_{\mathrm{t}-1}$} & \multirow[b]{2}{*}{$\mathrm{R}^{2}$} & \multicolumn{2}{|c|}{$\mathrm{CF} / \mathrm{A}_{\mathrm{t}-1}$} & \multicolumn{2}{|c|}{$\mathrm{Q}_{\mathrm{t}-1}$} & \multirow[b]{2}{*}{$\mathrm{R}^{2}$} \\
\hline & & $b$ & t-stat & c & t-stat & & $b$ & t-stat & $c$ & t-stat & \\
\hline 1 Low & 30,041 & 0.3699 & 59.78 & 0.0049 & 4.96 & 0.12 & 0.2972 & 47.15 & 0.0062 & 6.16 & 0.49 \\
\hline 2 & 24,375 & 0.3428 & 50.10 & 0.0137 & 15.32 & 0.12 & 0.2618 & 39.61 & 0.0221 & 25.10 & 0.55 \\
\hline 3 & 20,386 & 0.2285 & 36.73 & 0.0140 & 17.36 & 0.09 & 0.1830 & 29.91 & 0.0229 & 30.26 & 0.57 \\
\hline 4 & 15,615 & 0.1174 & 25.88 & 0.0140 & 26.99 & 0.09 & 0.0749 & 14.26 & 0.0178 & 35.12 & 0.55 \\
\hline 5 High & 9,790 & 0.0737 & 17.78 & 0.0095 & 24.62 & 0.09 & 0.0405 & 7.96 & 0.0129 & 33.68 & 0.55 \\
\hline
\end{tabular}




\section{Table 5 Cont'd}

\begin{tabular}{|c|c|c|c|c|c|c|c|c|c|c|c|}
\hline \multirow{3}{*}{$\begin{array}{l}\text { Panel B } \\
\mathrm{KZ}_{\text {med }}\end{array}$} & \multicolumn{6}{|c|}{ Panel B1: Panel Regression for Each KZ Index Quintile } & \multicolumn{5}{|c|}{ Panel B2: With Firm-fixed Effects } \\
\hline & \multirow[b]{2}{*}{ Firm Year } & \multicolumn{2}{|c|}{$\mathrm{CF} / \mathrm{A}_{\mathrm{t}-1}$} & \multicolumn{2}{|c|}{$\mathrm{Q}_{\mathrm{t}-1}$} & \multirow[b]{2}{*}{$\mathrm{R}^{2}$} & \multicolumn{2}{|c|}{$\mathrm{CF} / \mathrm{A}_{\mathrm{t}-1}$} & \multicolumn{2}{|c|}{$\mathrm{Q}_{\mathrm{t}-1}$} & \multirow[b]{2}{*}{$\mathrm{R}^{2}$} \\
\hline & & $b$ & t-stat & $C$ & t-stat & & $b$ & t-stat & $C$ & t-stat & \\
\hline $1 \mathrm{Low}$ & 19,322 & 0.1113 & 33.86 & 0.0065 & 24.83 & 0.09 & 0.0923 & 23.12 & 0.0080 & 27.00 & 0.55 \\
\hline 2 & 21,267 & 0.1451 & 41.76 & 0.0111 & 32.61 & 0.11 & 0.0880 & 21.62 & 0.0128 & 34.77 & 0.52 \\
\hline 3 & 24,739 & 0.2098 & 48.98 & 0.0193 & 39.27 & 0.14 & 0.1419 & 30.02 & 0.0205 & 39.32 & 0.54 \\
\hline 4 & 20,841 & 0.2721 & 44.43 & 0.0274 & 36.80 & 0.14 & 0.1756 & 28.60 & 0.0317 & 40.94 & 0.57 \\
\hline 5 High & 14,038 & 0.2875 & 32.87 & 0.0421 & 33.72 & 0.13 & 0.1894 & 19.35 & 0.0509 & 34.76 & 0.56 \\
\hline \multirow[t]{2}{*}{ Panel C } & \multicolumn{6}{|c|}{ Panel C1: Panel Regression for Each WW Index Quintile } & \multicolumn{4}{|c|}{ Panel C2: With Firm-fixed Effects } & \\
\hline & \multicolumn{3}{|c|}{$\mathrm{CF} / \mathrm{A}_{\mathrm{t}-1}$} & \multicolumn{2}{|c|}{$\mathrm{Q}_{\mathrm{t}-1}$} & & \multicolumn{2}{|c|}{$\mathrm{CF} / \mathrm{A}_{\mathrm{t}-1}$} & \multicolumn{2}{|c|}{$\mathrm{Q}_{\mathrm{t}-1}$} & \\
\hline $\mathrm{WW}_{\text {med }}$ & Firm Year & $b$ & t-stat & $C$ & t-stat & $\mathrm{R}^{2}$ & $b$ & t-stat & $C$ & t-stat & $\mathrm{R}^{2}$ \\
\hline $1 \mathrm{Low}$ & 34,297 & 0.4017 & 66.80 & -0.0008 & -1.96 & 0.14 & 0.3386 & 59.02 & 0.0068 & 15.64 & 0.54 \\
\hline 2 & 22,478 & 0.2880 & 45.15 & 0.0068 & 14.34 & 0.12 & 0.2180 & 35.62 & 0.0125 & 23.77 & 0.55 \\
\hline 3 & 18,054 & 0.2236 & 36.90 & 0.0101 & 19.46 & 0.10 & 0.1514 & 25.19 & 0.0168 & 29.62 & 0.56 \\
\hline 4 & 15,173 & 0.1440 & 27.29 & 0.0122 & 21.80 & 0.07 & 0.0834 & 14.75 & 0.0183 & 30.30 & 0.52 \\
\hline 5 High & 10,205 & 0.0819 & 17.86 & 0.0121 & 21.89 & 0.06 & 0.0386 & 7.33 & 0.0165 & 27.59 & 0.57 \\
\hline \multirow[t]{2}{*}{ Panel D } & \multicolumn{6}{|c|}{ Panel D1: Panel Regression for Each SA Index Quintile } & \multicolumn{4}{|c|}{ Panel D2: Within Firm-fixed Effects } & \\
\hline & \multicolumn{3}{|c|}{$\mathrm{CF} / \mathrm{A}_{\mathrm{t}-1}$} & \multicolumn{2}{|c|}{$\mathrm{Q}_{\mathrm{t}-1}$} & & \multicolumn{2}{|c|}{$\mathrm{CF} / \mathrm{A}_{\mathrm{t}-1}$} & \multicolumn{2}{|c|}{$\mathrm{Q}_{\mathrm{t}-1}$} & \\
\hline $\mathrm{SA}_{\text {med }}$ & Firm Year & $b$ & t-stat & $C$ & t-stat & $\mathrm{R}^{2}$ & $b$ & t-stat & $C$ & t-stat & $\mathrm{R}^{2}$ \\
\hline 1 Low & 40,490 & 0.3355 & 66.35 & 0.0024 & 6.35 & 0.12 & 0.2881 & 59.24 & 0.0092 & 22.93 & 0.50 \\
\hline 2 & 21,494 & 0.2703 & 43.93 & 0.0098 & 19.78 & 0.12 & 0.1909 & 31.79 & 0.0159 & 29.57 & 0.56 \\
\hline 3 & 16,854 & 0.1628 & 30.54 & 0.0102 & 19.76 & 0.08 & 0.1015 & 18.07 & 0.0160 & 28.39 & 0.54 \\
\hline 4 & 13,429 & 0.1317 & 26.93 & 0.0127 & 23.68 & 0.08 & 0.0772 & 13.94 & 0.0178 & 29.98 & 0.56 \\
\hline 5 High & 7,940 & 0.0787 & 14.74 & 0.0109 & 17.44 & 0.05 & 0.0330 & 5.11 & 0.0161 & 22.98 & 0.61 \\
\hline
\end{tabular}


Table 6: ICFS Interacted with Initial AI and Financial Constraint

This table reports the results of regressions where the dependent variable is Capex/ $A_{t}$ (corporate capital investment in year $t$ ), and the main explanatory variables are $C F / A_{t-1}$ (cash flow in year $t-1$ ), $\mathrm{Q}_{\mathrm{t}-1}$ (Tobin's $\mathrm{q}$ in year $t-1$, which has a correlation of 0.98 with market-to-book ratio, $\left.\mathrm{M} / \mathrm{B}_{\mathrm{t}-1}\right)$ and their interaction terms. Other variables include Initial AI (growth type) as well as the time series medians for the KZ, WW, and SA indexes (financial constraints). The index variables also enter in interaction terms, where various combinations generate 8 different regression specifications. All variables are standardized. Panel A shows the results from pooled OLS panel regressions. Panel B shows the results with firm-fixed effects. The sample period is 1971-2006.

\begin{tabular}{|c|c|c|c|c|c|c|c|c|}
\hline \multicolumn{9}{|c|}{ Panel A: Regression with ICFS Interacted with Growth Type and Financial Constraint } \\
\hline & $(1)$ & $(2)$ & $(3)$ & $(4)$ & $(5)$ & $(6)$ & $(7)$ & $(8)$ \\
\hline Intercept & $\begin{array}{r}-0.002 \\
(-0.79)\end{array}$ & $\begin{array}{r}0.028 \\
(9.05) \\
\end{array}$ & $\begin{array}{r}-0.045 \\
(-14.17) \\
\end{array}$ & $\begin{array}{r}-0.032 \\
(-10.31) \\
\end{array}$ & $\begin{array}{r}0.025 \\
(7.99) \\
\end{array}$ & $\begin{array}{r}-0.041 \\
(-12.74) \\
\end{array}$ & $\begin{array}{l}-0.030 \\
(-9.47) \\
\end{array}$ & $\begin{array}{r}-0.0188 \\
(-5.84) \\
\end{array}$ \\
\hline Initial AI & $\begin{array}{r}-0.059 \\
(-15.03) \\
\end{array}$ & & & & $\begin{array}{r}-0.042 \\
(-10.99) \\
\end{array}$ & $\begin{array}{r}-0.043 \\
(-10.81) \\
\end{array}$ & $\begin{array}{r}-0.048 \\
(-12.23) \\
\end{array}$ & $\begin{array}{l}-0.021 \\
(-5.28) \\
\end{array}$ \\
\hline $\mathrm{KZ}_{\text {med }}$ & & $\begin{array}{r}0.146 \\
(46.99)\end{array}$ & & & $\begin{array}{r}0.149 \\
(47.75)\end{array}$ & & & $\begin{array}{r}0.176 \\
(54.85)\end{array}$ \\
\hline $\mathrm{WW}_{\text {med }}$ & & & $\begin{array}{r}0.034 \\
(10.87)\end{array}$ & & & $\begin{array}{r}0.036 \\
(11.50)\end{array}$ & & $\begin{array}{l}-0.028 \\
(-4.18)\end{array}$ \\
\hline $\mathrm{SA}_{\text {med }}$ & & & & $\begin{array}{l}0.019 \\
(6.02)\end{array}$ & & & $\begin{array}{r}0.022 \\
(7.18)\end{array}$ & $\begin{array}{r}0.035 \\
(5.49)\end{array}$ \\
\hline $\mathrm{CF} / \mathrm{A}_{\mathrm{t}-1}$ & $\begin{array}{r}0.264 \\
(81.23)\end{array}$ & $\begin{array}{r}0.275 \\
(90.06)\end{array}$ & $\begin{array}{r}0.384 \\
(85.27)\end{array}$ & $\begin{array}{r}0.347 \\
(83.87)\end{array}$ & $\begin{array}{r}0.300 \\
(92.20)\end{array}$ & $\begin{array}{r}0.389 \\
(85.69)\end{array}$ & $\begin{array}{r}0.357 \\
(85.03)\end{array}$ & $\begin{array}{r}0.441 \\
(97.04)\end{array}$ \\
\hline $\begin{array}{l}\mathrm{CF} / \mathrm{A}_{\mathrm{t}-1} \\
\quad \text { *Initial AI }\end{array}$ & $\begin{array}{r}-0.058 \\
(-27.55) \\
\end{array}$ & & & & $\begin{array}{r}-0.054 \\
(-26.14) \\
\end{array}$ & $\begin{array}{r}-0.039 \\
(-18.32) \\
\end{array}$ & $\begin{array}{r}-0.045 \\
(-21.16) \\
\end{array}$ & $\begin{array}{r}-0.034 \\
(-16.32) \\
\end{array}$ \\
\hline $\mathrm{CF} / \mathrm{A}_{\mathrm{t}-1} * \mathrm{KZ}_{\text {med }}$ & & $\begin{array}{r}0.069 \\
(30.13)\end{array}$ & & & $\begin{array}{r}0.064 \\
(28.04)\end{array}$ & & & $\begin{array}{r}0.067 \\
(29.13)\end{array}$ \\
\hline $\mathrm{CF} / \mathrm{A}_{\mathrm{t}-1} * \mathrm{WW}_{\mathrm{med}}$ & & & $\begin{array}{r}-0.146 \\
(-40.94)\end{array}$ & & & $\begin{array}{r}-0.133 \\
(-36.66)\end{array}$ & & $\begin{array}{r}-0.165 \\
(-24.22)\end{array}$ \\
\hline $\mathrm{CF} / \mathrm{A}_{\mathrm{t}-1} * \mathrm{SA} \mathrm{A}_{\mathrm{med}}$ & & & & $\begin{array}{r}-0.120 \\
(-37.24)\end{array}$ & & & $\begin{array}{r}-0.108 \\
(-33.22)\end{array}$ & $\begin{array}{r}0.000 \\
(-0.01)\end{array}$ \\
\hline $\mathrm{Q}_{\mathrm{t}-1}$ & $\begin{array}{r}0.178 \\
(52.63) \\
\end{array}$ & $\begin{array}{r}0.221 \\
(69.81) \\
\end{array}$ & $\begin{array}{r}0.091 \\
(26.12) \\
\end{array}$ & $\begin{array}{r}0.110 \\
(32.03) \\
\end{array}$ & $\begin{array}{r}0.257 \\
(69.92) \\
\end{array}$ & $\begin{array}{r}0.117 \\
(30.80) \\
\end{array}$ & $\begin{array}{r}0.134 \\
(35.88) \\
\end{array}$ & $\begin{array}{r}0.206 \\
(49.86) \\
\end{array}$ \\
\hline $\mathrm{Q}_{\mathrm{t}-1} *$ Initial AI & $\begin{array}{l}-0.015 \\
(-7.80) \\
\end{array}$ & & & & $\begin{array}{l}-0.019 \\
(-9.50) \\
\end{array}$ & $\begin{array}{l}-0.017 \\
(-8.40) \\
\end{array}$ & $\begin{array}{l}-0.016 \\
(-7.92) \\
\end{array}$ & $\begin{array}{r}-0.021 \\
(-10.69) \\
\end{array}$ \\
\hline $\mathrm{Q}_{\mathrm{t}-1} * \mathrm{KZ}_{\mathrm{med}}$ & & $\begin{array}{r}0.071 \\
(28.86)\end{array}$ & & & $\begin{array}{r}0.070 \\
(26.86)\end{array}$ & & & $\begin{array}{r}0.065 \\
(24.35)\end{array}$ \\
\hline $\mathrm{Q}_{\mathrm{t}-1} * \mathrm{WW}_{\text {med }}$ & & & $\begin{array}{r}0.068 \\
(20.85)\end{array}$ & & & $\begin{array}{r}0.060 \\
(18.06)\end{array}$ & & $\begin{array}{r}0.020 \\
(2.90)\end{array}$ \\
\hline $\mathrm{Q}_{\mathrm{t}-1} * \mathrm{SA}_{\mathrm{med}}$ & & & & $\begin{array}{r}0.045 \\
(14.37)\end{array}$ & & & $\begin{array}{r}0.039 \\
(12.48)\end{array}$ & $\begin{array}{r}0.009 \\
(1.41)\end{array}$ \\
\hline Firm Year & 100,205 & 100,205 & 100,205 & 100,205 & 100,205 & 100,205 & 100,205 & 100,205 \\
\hline $\mathrm{R}^{2}$ & 0.09 & 0.12 & 0.10 & 0.10 & 0.13 & 0.11 & 0.10 & 0.14 \\
\hline
\end{tabular}


Table 6 Cont'd

\begin{tabular}{|c|c|c|c|c|c|c|c|c|}
\hline \multicolumn{9}{|c|}{ Panel B: Regression with Firm-fixed Effects } \\
\hline & (1) & $(2)$ & (3) & $(4)$ & (5) & (6) & (7) & (8) \\
\hline $\mathrm{CF} / \mathrm{A}_{\mathrm{t}-1}$ & $\begin{array}{r}0.214 \\
(58.41)\end{array}$ & $\begin{array}{r}0.188 \\
(55.23)\end{array}$ & $\begin{array}{r}0.304 \\
(68.55)\end{array}$ & $\begin{array}{r}0.272 \\
(67.08)\end{array}$ & $\begin{array}{r}0.211 \\
(58.13)\end{array}$ & $\begin{array}{r}0.316 \\
(69.82)\end{array}$ & $\begin{array}{r}0.288 \\
(68.68)\end{array}$ & $\begin{array}{r}0.309 \\
(68.32)\end{array}$ \\
\hline $\begin{array}{l}\mathrm{CF} / \mathrm{A}_{\mathrm{t}-1} \\
\quad{ }^{*} \text { Initial AI }\end{array}$ & $\begin{array}{r}-0.065 \\
(-23.02) \\
\end{array}$ & & & & $\begin{array}{r}-0.058 \\
(-20.26) \\
\end{array}$ & $\begin{array}{r}-0.048 \\
(-16.87) \\
\end{array}$ & $\begin{array}{r}-0.052 \\
(-18.18) \\
\end{array}$ & $\begin{array}{r}-0.042 \\
(-14.47) \\
\end{array}$ \\
\hline $\mathrm{CF} / \mathrm{A}_{\mathrm{t}-1} * \mathrm{KZ}_{\mathrm{med}}$ & & $\begin{array}{r}0.055 \\
(15.75)\end{array}$ & & & $\begin{array}{r}0.042 \\
(11.78)\end{array}$ & & & $\begin{array}{r}0.048 \\
(13.49)\end{array}$ \\
\hline $\mathrm{CF} / \mathrm{A}_{\mathrm{t}-1} * \mathrm{WW}_{\text {med }}$ & & & $\begin{array}{r}-0.164 \\
(-40.15)\end{array}$ & & & $\begin{array}{r}-0.154 \\
(-37.35)\end{array}$ & & $\begin{array}{r}-0.129 \\
(-15.89)\end{array}$ \\
\hline $\mathrm{CF} / \mathrm{A}_{\mathrm{t}-1} * \mathrm{SA}_{\mathrm{med}}$ & & & & $\begin{array}{r}-0.137 \\
(-37.81)\end{array}$ & & & $\begin{array}{r}-0.128 \\
(-35.21)\end{array}$ & $\begin{array}{l}-0.025 \\
(-3.45)\end{array}$ \\
\hline $\mathrm{Q}_{\mathrm{t}-1}$ & $\begin{array}{r}0.241 \\
(61.63) \\
\end{array}$ & $\begin{array}{r}0.268 \\
(76.97) \\
\end{array}$ & $\begin{array}{r}0.181 \\
(47.69) \\
\end{array}$ & $\begin{array}{r}0.196 \\
(53.32) \\
\end{array}$ & $\begin{array}{r}0.307 \\
(73.18) \\
\end{array}$ & $\begin{array}{r}0.200 \\
(47.87) \\
\end{array}$ & $\begin{array}{r}0.213 \\
(52.06) \\
\end{array}$ & $\begin{array}{r}0.281 \\
(60.39) \\
\end{array}$ \\
\hline $\mathrm{Q}_{\mathrm{t}-1} *$ Initial AI & $\begin{array}{l}-0.018 \\
(-7.73)\end{array}$ & & & & $\begin{array}{l}-0.011 \\
(-4.97)\end{array}$ & $\begin{array}{l}-0.023 \\
(-9.95)\end{array}$ & $\begin{array}{l}-0.021 \\
(-9.19)\end{array}$ & $\begin{array}{l}-0.014 \\
(-6.30)\end{array}$ \\
\hline $\mathrm{Q}_{\mathrm{t}-1} * \mathrm{KZ}_{\mathrm{med}}$ & & $\begin{array}{r}0.121 \\
(38.15)\end{array}$ & & & $\begin{array}{r}0.128 \\
(37.87)\end{array}$ & & & $\begin{array}{r}0.126 \\
(35.80)\end{array}$ \\
\hline $\mathrm{Q}_{\mathrm{t}-1} * \mathrm{WW}_{\text {med }}$ & & & $\begin{array}{r}0.061 \\
(16.48)\end{array}$ & & & $\begin{array}{r}0.060 \\
(16.20)\end{array}$ & & $\begin{array}{l}-0.002 \\
(-0.20)\end{array}$ \\
\hline $\mathrm{Q}_{\mathrm{t}-1} * \mathrm{SA}_{\mathrm{med}}$ & & & & $\begin{array}{r}0.044 \\
(12.54)\end{array}$ & & & $\begin{array}{r}0.044 \\
(12.55)\end{array}$ & $\begin{array}{r}0.026 \\
(3.54)\end{array}$ \\
\hline Firm Year & 100,205 & 100,205 & 100,205 & 100,205 & 100,205 & 100,205 & 100,205 & 100,205 \\
\hline $\mathrm{R}^{2}$ & 0.54 & 0.55 & 0.55 & 0.55 & 0.55 & 0.55 & 0.55 & 0.56 \\
\hline
\end{tabular}


Table 7: ICFS Interacted with Investment Style and Financial Constraint

This table reports the results of regressions where the dependent variable is Capex/ $A_{t}$ (corporate capital investment in year $t$ ), and the main explanatory variables are $C F / A_{t-1}$ (cash flows in year $t-1$ ), $Q_{t-1}$ (Tobin's q in year $t-1$, which has a correlation of 0.98 with market-to-book ratio, $\mathrm{M} / \mathrm{B}_{\mathrm{t}-1}$ ) and their interaction terms. Other variables include $R \& D /(C a p e x+R \& D)_{t-1}$, also denoted as Investyle $t_{t-1}$, a proxy for investment style, and annual values of the KZ, WW and SA indexes (financial constraints), all lagged one year. These index variables also enter in interaction terms, where various combinations generate 8 different regression specifications. All variables are standardized. Panel A shows the results from pooled OLS panel regressions. Panel B shows the results with firm-fixed effects. The sample period is 1971-2006.

Panel A: Regression with ICFS Interacted with Investment Style and Financial Constraint

\begin{tabular}{|c|c|c|c|c|c|c|c|c|}
\hline Intercept & $\begin{array}{r}(1) \\
-0.004 \\
(-1.25) \\
\end{array}$ & $\begin{array}{r}(2) \\
0.000 \\
(0.14) \\
\end{array}$ & $\begin{array}{r}(3) \\
-0.037 \\
(-12.25)\end{array}$ & $\begin{array}{r}(4) \\
-0.022 \\
(-7.22) \\
\end{array}$ & $\begin{array}{r}(5) \\
-0.006 \\
(-2.11) \\
\end{array}$ & $\begin{array}{r}6) \\
-0.025 \\
(-8.16) \\
\end{array}$ & $\begin{array}{r}(7) \\
-0.017 \\
(-5.62) \\
\end{array}$ & $\begin{array}{r}(8) \\
-0.0175 \\
(-5.64) \\
\end{array}$ \\
\hline Investyle $_{t-1}$ & $\begin{array}{r}-0.220 \\
(-69.68) \\
\end{array}$ & & & & $\begin{array}{r}-0.215 \\
(-68.44) \\
\end{array}$ & $\begin{array}{r}-0.219 \\
(-69.48) \\
\end{array}$ & $\begin{array}{r}-0.219 \\
(-69.05) \\
\end{array}$ & $\begin{array}{r}-0.209 \\
(-65.67) \\
\end{array}$ \\
\hline $\mathrm{KZ}_{\mathrm{t}-1}$ & & $\begin{array}{r}0.037 \\
(11.68)\end{array}$ & & & $\begin{array}{r}0.024 \\
(6.93)\end{array}$ & & & $\begin{array}{r}0.041 \\
(11.76)\end{array}$ \\
\hline $\mathrm{WW}_{\mathrm{t}-1}$ & & & $\begin{array}{r}0.058 \\
(18.81)\end{array}$ & & & $\begin{array}{r}0.082 \\
(27.49)\end{array}$ & & $\begin{array}{l}-0.038 \\
(-6.92)\end{array}$ \\
\hline $\mathrm{SA}_{\mathrm{t}-1}$ & & & & $\begin{array}{r}0.104 \\
(34.07)\end{array}$ & & & $\begin{array}{r}0.113 \\
(38.26)\end{array}$ & $\begin{array}{r}0.141 \\
(25.88)\end{array}$ \\
\hline $\mathrm{CF} / \mathrm{A}_{\mathrm{t}-1}$ & $\begin{array}{r}0.276 \\
(76.90) \\
\end{array}$ & $\begin{array}{r}0.239 \\
(78.48) \\
\end{array}$ & $\begin{array}{r}0.349 \\
(83.93) \\
\end{array}$ & $\begin{array}{r}0.339 \\
(84.52) \\
\end{array}$ & $\begin{array}{r}0.276 \\
(76.12) \\
\end{array}$ & $\begin{array}{r}0.339 \\
(79.58) \\
\end{array}$ & $\begin{array}{r}0.338 \\
(79.39) \\
\end{array}$ & $\begin{array}{r}0.346 \\
(78.22) \\
\end{array}$ \\
\hline $\begin{array}{l}\mathrm{CF} / \mathrm{A}_{\mathrm{t}-1} \\
\quad \text { *Investyle } \\
\mathrm{t}-1\end{array}$ & $\begin{array}{r}-0.115 \\
(-51.48) \\
\end{array}$ & & & & $\begin{array}{r}-0.113 \\
(-50.27)\end{array}$ & $\begin{array}{r}-0.100 \\
(-43.11)\end{array}$ & $\begin{array}{r}-0.106 \\
(-47.30) \\
\end{array}$ & $\begin{array}{r}-0.099 \\
(-42.30) \\
\end{array}$ \\
\hline $\mathrm{CF} / \mathrm{A}_{\mathrm{t}-1} * \mathrm{KZ}_{\mathrm{t}-1}$ & & $\begin{array}{r}0.015 \\
(10.56)\end{array}$ & & & $\begin{array}{c}0.012 \\
(8.82)\end{array}$ & & & $\begin{array}{r}0.011 \\
(8.03)\end{array}$ \\
\hline $\mathrm{CF} / \mathrm{A}_{\mathrm{t}-1} * \mathrm{WW}_{\mathrm{t}-1}$ & & & $\begin{array}{r}-0.096 \\
(-31.52)\end{array}$ & & & $\begin{array}{r}-0.054 \\
(-17.58)\end{array}$ & & $\begin{array}{l}-0.031 \\
(-6.40)\end{array}$ \\
\hline $\mathrm{CF} / \mathrm{A}_{\mathrm{t}-1} * \mathrm{SA}_{\mathrm{t}-1}$ & & & & $\begin{array}{r}-0.090 \\
(-30.01)\end{array}$ & & & $\begin{array}{r}-0.054 \\
(-18.43)\end{array}$ & $\begin{array}{l}-0.034 \\
(-7.23)\end{array}$ \\
\hline $\mathrm{Q}_{\mathrm{t}-1}$ & $\begin{array}{r}0.254 \\
(70.93) \\
\end{array}$ & $\begin{array}{r}0.173 \\
(51.95) \\
\end{array}$ & $\begin{array}{r}0.081 \\
(23.18) \\
\end{array}$ & $\begin{array}{r}0.075 \\
(20.60) \\
\end{array}$ & $\begin{array}{r}0.256 \\
(67.06) \\
\end{array}$ & $\begin{array}{r}0.197 \\
(50.31) \\
\end{array}$ & $\begin{array}{r}0.189 \\
(46.51) \\
\end{array}$ & $\begin{array}{r}0.202 \\
(47.52) \\
\end{array}$ \\
\hline $\mathrm{Q}_{\mathrm{t}-1} *$ Investyle $_{\mathrm{t}-1}$ & $\begin{array}{r}-0.073 \\
(-29.96) \\
\end{array}$ & & & & $\begin{array}{r}-0.072 \\
(-28.92) \\
\end{array}$ & $\begin{array}{r}-0.077 \\
(-30.50) \\
\end{array}$ & $\begin{array}{r}-0.072 \\
(-29.92) \\
\end{array}$ & $\begin{array}{r}-0.078 \\
(-30.58) \\
\end{array}$ \\
\hline $\mathrm{Q}_{\mathrm{t}-1} * \mathrm{KZ}_{\mathrm{t}-1}$ & & $\begin{array}{r}0.021 \\
(16.18)\end{array}$ & & & $\begin{array}{r}0.011 \\
(6.57)\end{array}$ & & & $\begin{array}{r}0.004 \\
(2.32)\end{array}$ \\
\hline $\mathrm{Q}_{\mathrm{t}-1} * \mathrm{WW}_{\mathrm{t}-1}$ & & & $\begin{array}{r}0.075 \\
(24.20)\end{array}$ & & & $\begin{array}{r}0.068 \\
(22.35)\end{array}$ & & $\begin{array}{r}0.056 \\
(9.84)\end{array}$ \\
\hline $\mathrm{Q}_{\mathrm{t}-1} * \mathrm{SA}_{\mathrm{t}-1}$ & & & & $\begin{array}{r}0.072 \\
(25.78)\end{array}$ & & & $\begin{array}{r}0.054 \\
(19.92)\end{array}$ & $\begin{array}{r}0.004 \\
(0.77)\end{array}$ \\
\hline Firm Year & 100,205 & 100,205 & 100,205 & 100,205 & 100,205 & 100,205 & 100,205 & 100,205 \\
\hline $\mathrm{R}^{2}$ & 0.15 & 0.08 & 0.10 & 0.11 & 0.15 & 0.16 & 0.17 & 0.17 \\
\hline
\end{tabular}


Table 7 Cont'd

\begin{tabular}{|c|c|c|c|c|c|c|c|c|}
\hline \multicolumn{9}{|c|}{ Panel B: Regression with Firm-fixed Effects } \\
\hline \multirow{3}{*}{$\mathrm{CF} / \mathrm{A}_{\mathrm{t}-1}$} & $(1)$ & (2) & (3) & (4) & (5) & $(6)$ & $(7)$ & $(8)$ \\
\hline & 0.255 & 0.180 & 0.246 & 0.226 & 0.244 & 0.279 & 0.279 & 0.281 \\
\hline & (65.86) & $(53.06)$ & $(57.93)$ & $(55.15)$ & (63.58) & (63.62) & $(64.26)$ & $(63.34)$ \\
\hline \multirow{2}{*}{$\begin{array}{l}\mathrm{CF} / \mathrm{A}_{\mathrm{t}-1} \\
\quad * \text { Investyle }_{\mathrm{t}-1}\end{array}$} & -0.100 & & & & -0.094 & -0.087 & -0.098 & -0.087 \\
\hline & $(-40.63)$ & & & & $(-38.42)$ & $(-34.38)$ & $(-39.39)$ & $(-34.02)$ \\
\hline \multirow[t]{2}{*}{$\mathrm{CF} / \mathrm{A}_{\mathrm{t}-1} * \mathrm{KZ}_{\mathrm{t}-1}$} & & 0.004 & & & 0.005 & & & 0.004 \\
\hline & & (3.23) & & & $(4.07)$ & & & $(2.98)$ \\
\hline \multirow[t]{2}{*}{$\mathrm{CF} / \mathrm{A}_{\mathrm{t}-1} * \mathrm{WW}_{\mathrm{t}-1}$} & & & -0.067 & & & -0.037 & & -0.036 \\
\hline & & & $(-22.24)$ & & & $(-12.12)$ & & $(-7.77)$ \\
\hline \multirow[t]{2}{*}{$\mathrm{CF} / \mathrm{A}_{\mathrm{t}-1} * \mathrm{SA}_{\mathrm{t}-1}$} & & & & -0.042 & & & -0.024 & -0.003 \\
\hline & & & & $(-14.24)$ & & & $(-8.32)$ & $(-0.73)$ \\
\hline \multirow[t]{2}{*}{$\mathrm{Q}_{\mathrm{t}-1}$} & 0.290 & 0.240 & 0.171 & 0.176 & 0.288 & 0.242 & 0.240 & 0.243 \\
\hline & $(73.31)$ & $(65.12)$ & $(43.56)$ & $(43.56)$ & $(68.03)$ & (55.17) & $(53.80)$ & $(52.32)$ \\
\hline \multirow[t]{2}{*}{$\mathrm{Q}_{\mathrm{t}-1} *$ Investyle $_{\mathrm{t}-1}$} & -0.086 & & & & -0.086 & -0.094 & -0.089 & -0.093 \\
\hline & $(-33.55)$ & & & & $(-32.21)$ & $(-34.88)$ & $(-34.54)$ & $(-34.04)$ \\
\hline \multirow[t]{2}{*}{$\mathrm{Q}_{\mathrm{t}-1} * \mathrm{KZ}_{\mathrm{t}-1}$} & & 0.024 & & & 0.009 & & & 0.007 \\
\hline & & $(19.20)$ & & & $(6.91)$ & & & (5.34) \\
\hline \multirow[t]{2}{*}{$\mathrm{Q}_{\mathrm{t}-1} * \mathrm{WW}_{\mathrm{t}-1}$} & & & 0.061 & & & 0.073 & & 0.057 \\
\hline & & & (19.52) & & & (23.52) & & (10.17) \\
\hline \multirow[t]{2}{*}{$\mathrm{Q}_{\mathrm{t}-1} * \mathrm{SA}_{\mathrm{t}-1}$} & & & & 0.058 & & & 0.061 & 0.018 \\
\hline & & & & (21.63) & & & (23.15) & (3.54) \\
\hline \multirow{2}{*}{$\begin{array}{l}\text { Firm Year } \\
\mathrm{R}^{2}\end{array}$} & 100,205 & 100,205 & 100,205 & 100,205 & 100,205 & 100,205 & 100,205 & 100,205 \\
\hline & 0.56 & 0.55 & 0.55 & 0.54 & 0.56 & 0.56 & 0.56 & 0.56 \\
\hline
\end{tabular}

